\title{
Abbreviations
}

Bijdragen tot de Taal-, Land-en Volkenkunde (Journal of the Humanities and Social Sciences of Southeast Asia)

HDC Historical Documentation Center for Dutch Protestantism

$I G$ De Indische Gids

$I P O$ Overzicht van de Inlandsche en Maleisch-Chineesche Pers (Survey of the Native and Malay-Chinese Press)

JSEAS Journal of Southeast Asian Studies

JWH Journal of World History

KITLV Royal Netherlands Institute for Southeast Asian and Caribbean Studies

KT Koloniaal Tijdschrift

NL-HaNA Nationaal Archief, Den Haag (National Archives, The Hague)

$N N I$ Het Nieuws van den Dag voor Nederlandsch-Indië

PPBB Persatoean Prijaji Bestuur Boemipoetera (Association of Indigenous Civil Servants)

SEAP Southeast Asia Program Publications

TBB Tijdschrift voor het Binnenlandsch Bestuur

TNI Tijdschrift voor Nederlandsch-Indië

UBL Leiden University Library, Special Collections

VOC Vereenigde Oost-Indische Compagnie (Dutch East India Company)

WVI Weekblad voor Indië

\section{Introduction. The Performance of Power}

I. T. Hellwig to G. A. J. Hazeu, February 25, 1913, in Collection Hazeu, H Io83, no. 29 , UBL.

2. Indonesian independence was declared on August 17, 1945; however, it took four years of violent conflict before the Dutch's eventual recognition of it on December 27, 1949 .

3. Heather Sutherland, The Making of a Bureaucratic Elite: The Colonial Transformation of the Javanese Priyayi (Singapore: Heinemann Educational Books, 1979); H. W. van den Doel, De stille macht: het Europese binnenlands bestuur op Java en Madoera, 1808-1942 (Amsterdam: Bert Bakker, 1994); C. W. Newbury, "Patrons, 
Clients, and Empire: The Subordination of Indigenous Hierarchies in Asia and Africa," Journal of World History iI, no. 2 (2000): 227-63. An exception is Sanne Ravensbergen, "Courtrooms of Conflict: Criminal Law, Local Elites and Legal Pluralities in Colonial Java” (PhD diss., Leiden University, 2018), http://hdl.handle.net/1887/61039.

4. Jean Gelman Taylor, The Social World of Batavia: Europeans and Eurasians in Colonial Indonesia (Madison: University of Wisconsin Press, 1983); Ulbe Bosma and Remco Raben, Being "Dutch" in the Indies: A History of Creolisation and Empire, Isoo1920 (Singapore: NUS Press, 2008); Leonard Blussé, Strange Company: Chinese Settlers, Mestizo Women and the Dutch in VOC Batavia (Dordrecht: Foris, 1986).

5. Benedict Anderson, Language and Power: Exploring Political Cultures in Indonesia (Ithaca: Cornell University Press, 1990), 133-34.

6. O. W. Wolters, History, Culture, and Region in Southeast Asian Perspectives (Ithaca: SEAP, Cornell University, 1999), II-57; Jan Wisseman Christie, "Rāja and Rāma: The Classical State in Early Java," in Centers, Symbols, and Hierarchies: Essays of the Classical States of Southeast Asia, ed. Lorraine Gesick and Michael Aung-Thwin (New Haven: Yale University Southeast Asia Studies Monographs, 1983), 21-35; Soemarsaid Moertono, State and Statecraft in Old Java: A Study of the Later Mataram Period, I6th to Igth Century (Ithaca: SEAP, Cornell University, 198I), I4-24; Michael Adas, "From Avoidance to Confrontation: Peasant Protest in Precolonial and Colonial Southeast Asia," Comparative Studies in Society and History 23, no. 2 (April 1981): 217-47.

7. Anderson, Language and Power, 28.

8. Clifford Geertz, Negara: The Theatre State in Nineteenth-Century Bali (Princeton: Princeton University Press, 1980), I3.

9. Henk Schulte Nordholt, The Spell of Power: A History of Balinese Politics, I650-1940 (Leiden: KITLV Press, 1996).

Io. Jan Breman, Mobilizing Labour for the Global Coffee Market: Profits from an Unfree Work Regime in Colonial Java (Amsterdam: Amsterdam University Press, 2015), 262-71. II. John Pemberton, On the Subject of "Java" (Ithaca: Cornell University Press, 1994), IO, 22-23, 64-66.

I2. Antonio Gramsci, Selections from the Prison Notebooks of Antonio Gramsci, trans. Quentin Hoare and Geoffrey Nowell Smith (New York: International Publishers, 1972), 5-23, 52-58, 16I-70; Steve Jones, Antonio Gramsci (London; New York: Routledge, 2006); Walter L. Adamson, Hegemony and Revolution: A Study of Antonio Gramsci's Political and Cultural Theory (Berkeley: University of California Press, 1980); Perry Anderson, "The Antinomies of Antonio Gramsci," New Left Review i, no. 100 (1976): 5-78.

13. Douglas Haynes and Gyan Prakash, eds., Contesting Power: Resistance and Everyday Social Relations in South Asia (Berkeley: University of California Press, 1992); Dagmar Engels and Shula Marks, eds., Contesting Colonial Hegemony: State and Society in Africa and India (New York: British Academic Press, 1994); David Arnold, "Gramsci and Peasant Subalternity in India," Journal of Peasant Studies II, no. 4 (1984): 155-77; Bernard S. Cohn, Colonialism and its Forms of Knowledge: The British in India (Princeton: Princeton University Press, 1996).

I4. Breman, Mobilizing Labour, 347-67. 
I5. Jackson Lears, "The Concept of Cultural Hegemony: Problems and Possibilities," American Historical Review 90, no. 3 (1985): 567-93.

16. Ranajit Guha, Dominance without Hegemony: History and Power in Colonial India (Cambridge: Harvard University Press, 1997).

17. Gramsci, Prison Notebooks, 52-58, 16I-70.

I8. Sutherland, Bureaucratic Elite; Leslie H. Palmier, “The Javanese Nobility under the Dutch," Comparative Studies in Society and History 2, no. 2 (1960): 197-227.

19. James Rush, Opium to Java: Revenue Farming and Chinese Enterprise in Colonial Indonesia, I860-I9Io (Ithaca: Cornell University Press, 1990), 83-I35; Patricia Tjiook-Liem, De rechtspositie der Chinezen in Nederlands-Indië 1848-1942: wetgevingsbeleid tussen beginsel en belang (Amsterdam: Leiden University Press, 2009).

20. Jaap de Moor, "The Recruitment of Indonesian Soldiers for the Dutch Colonial Army, c. 1700-1950," in Guardians of Empire: The Armed Forces of the Colonial Powers. I700-I964, ed. David Killingray and David Omissi (Manchester: Manchester University Press, 1999), 53-69.

2r. Raymond Williams, Marxism and Literature (Oxford: Oxford University Press, 1977), 108-14.

22. James C. Scott, Domination and the Arts of Resistance: Hidden Transcripts (New Haven: Yale University Press, 1990); James C. Scott, Weapons of the Weak: Everyday Forms of Peasant Resistance (New Haven: Yale University Press, 1987).

23. Robert Elson, The Idea of Indonesia: A History (New York: Cambridge University Press, 2008), I-25.

24. Scott, Domination and the Arts of Resistance, 87; Ann Laura Stoler, Along the Archival Grain: Epistemic Anxieties and Colonial Common Sense (Princeton: Princeton University Press, 2009); Remco Raben, "Ethnic Disorder in VOC Asia: A Plea for Eccentric Reading", BMGN-Low Countries Historical Review, 134, no. 2 (2019): III5-28.

25. Michael Adas, "From Footdragging to Flight: The Evasive History of Peasant Avoidance Protest in South and South-East Asia," Journal of Peasant Studies 13, no. 2 (1986): 64-86; Breman, Mobilizing Labour, 347-67.

26. F. A. Stoett, Nederlandsche spreekwoorden, spreekwijzen, uitdrukkingen en gezegden (Zutphen: W. J. Thieme \& Cie, 1923-25), I8I.

27. Raden Adjeng Kartini to Stella Zeehandelaar, January 12, 1900, in Letters of a Javanese Princess, trans. Agnes Louise Symmers (Kuala Lumpur: Oxford University Press, 1976), 40-42. Also see Raden Adjeng Kartini, The Complete Kartini: The Collected Works of R. A. Kartini, trans. Joost J. P. Coté (Clayton: Monash University Publishing, 2013).

28. Jürgen Osterhammel, The Transformation of the World: A Global History of the Nineteenth Century (Princeton: Princeton University Press, 2015); Tony Ballantyne and Antoinette Burton, Empires and the Reach of the Global, 1870-1945 (Cambridge: Belknap Press of Harvard University Press, 2014).

29. Eric Tagliacozzo, "The Indies and the World: State Building, Promise, and Decay at a Transnational Moment, I910,” BKI II6, no. 2/3 (2010): 270-92; Kees van Dijk, The Netherlands Indies and the Great War, I9I4-19I8 (Leiden: KITLV Press, 2007) I-90. 
30. Elsbeth Locher-Scholten, Ethiek in fragmenten: vijf studies over koloniaal denken en doen van Nederlanders in de Indonesische Archipel, 1877-1942 (Utrecht: HES Publishers, 198I); Maarten Kuitenbrouwer, The Netherlands and the Rise of Modern Imperialism: Colonies and Foreign Policy, I870-1902 (New York: St. Martin's Press, 199I); Suzanne Moon, Technology and Ethical Idealism: A History of Development in the Netherlands East Indies (Leiden: CNWS Publications, 2007); Steven Wedema, "Ethiek" und Macht: die niederländisch-indische Kolonialverwaltung und indonesische Emanzipationsbestrebungen, I90I-1927 (Stuttgart: F. Steiner, 1998); Marieke Bloembergen and Remco Raben, eds., Het koloniale beschavingsoffensief: wegen naar het nieuwe Indië, I890-1950 (Leiden: KITLV Press, 2009); R. B. Cribb, ed., The Late Colonial State in Indonesia: Political and Economic Foundations of the Netherlands Indies, 1880-1942 (Leiden: KITLV Press, 1994); Wim Ravesteijn and Jan Kop, eds., For Profit and Prosperity: The Contribution Made by Dutch Engineers to Public Works in Indonesia, I800-2000 (Leiden: KITLV Press, 2008).

31. Fenneke Sysling, Racial Science and Human Diversity in Colonial Indonesia (Singapore: NUS Press, 2016); Frances Gouda, Dutch Culture Overseas: Colonial Practice in the Netherlands Indies, 1900-1942 (Amsterdam: Amsterdam University Press, 1995); Jan Breman, Piet de Rooy, and Ann Laura Stoler, eds., Imperial Monkey Business: Racial Supremacy in Social Darwinist Theory and Colonial Practice (Amsterdam: VU University Press, 1990).

32. Kartosiswojo, "Kamerdika’an," Sinar Djawa, April 8, I9I 4.

33. Bart Luttikhuis and Arnout H. C. van der Meer, "1913 in Indonesian History: Demanding Equality, Changing Mentality," TRaNS: Trans-Regional and-National Studies of Southeast Asia 8, no. 2 (2020): II5-33.

34. Locher-Scholten, Ethiek in fragmenten; Kees Groeneboer, Gateway to the West: The Dutch Language in Colonial Indonesia, I6oo-1950 (Amsterdam: Amsterdam University Press, 1998); Robert van Niel, The Emergence of the Modern Indonesian Elite (The Hague: W. van Hoeve, 1960); Rudolf Mrázek, Engineers of Happy Land: Technology and Nationalism in a Colony (Princeton: Princeton University Press, 2002); Andrew Goss, The Floracrats: State-Sponsored Science and the Failure of the Enlightenment in Indonesia (Madison: The University of Wisconsin Press, 2011).

35. Michael Francis Laffan, Islamic Nationhood and Colonial Indonesia: The Umma Below the Winds (New York: Routledge, 2003); Michael Laffan, The Making of Indonesian Islam: Orientalism and the Narration of a Sufi Past (Princeton: Princeton University Press, 201I); Chiara Formichi, "Indonesian Readings of Turkish History, I890s to I940s," in From Anatolia to Aceh: Ottomans, Turks and Southeast Asia, ed. A. C. S. Peacock and Annabel Teh Gallop (Oxford: Oxford University Press, 2015), 24I-60; Deliar Noer, The Modernist Muslim Movement in Indonesia, Igoo-1942 (Kuala Lumpur: Oxford University Press, 1973).

36. Takashi Shiraishi, An Age in Motion: Popular Radicalism in Java, I9I2-1926 (Ithaca: Cornell University Press, 1990); Akira Nagazumi, The Dawn of Indonesian Nationalism: The Early Years of the Budi Utomo, 1908-19I8 (Tokyo: Institute for Developing Studies, 1972); A. P. E. Korver, Sarekat Islam, I9I2-I9I6: opkomst, bloei en 
structuur van Indonesië's eerste massabeweging (Amsterdam, Historisch Seminarium van de Universiteit van Amsterdam, 1982); Chiara Formichi, Islam and the Making of the Nation: Kartosuwiryo and Political Islam in Twentieth-Century Indonesia (Leiden: KITLV Press, 20I2); Safrizal Rambe, Sarekat Islam: pelopor nasionalisme Indonesia, 1905-1942 (Jakarta: Yayasan Kebangkitan Insan Cendekia, 2008); Sartono Kartodirdjo, Pengantar sejarah Indonesia baru: Sejarah pergerakan nasional dari kolonialisme sampai nasionalisme, vol. 2 (Jakarta: Gramedia Pustaka Utama, 1992).

37. Ahmat Adam, The Vernacular Press and the Emergence of Modern Indonesian Consciousness (1855-1913) (Ithaca: Cornell University Press, 1995); Tom G. Hoogervorst, Language Ungoverned: Indonesia's Chinese Print Entrepreneurs, I9II-I949 (Ithaca: SEAP, Cornell University, 2021).

38. Hormat literally means "respect," but in this context refers to customary social deference and etiquette.

39. Shiraishi also discusses this alignment of interests between the colonial government and the nascent nationalist movement in An Age in Motion.

40. Henk Schulte Nordholt, ed., Outward Appearances: Dressing State and Society in Indonesia (Leiden: KITLV Press, 1997).

4I. Fridus Steijlen en Erik Willems, eds., Met ons alles goed: brieven en films uit Nederlands-Indië van de familie Kuyck (Zutphen: Walburg Pers, 2008), I24; Henk Schulte Nordholt, "Modernity and Cultural Citizenship in the Netherlands Indies: An Illustrated Hypothesis," JSEAS 42, no. 3 (October 2011): 454.

42. Bart Luttikhuis, "Negotiating Modernity: Europeanness in Late Colonial Indonesia, 1910-1942” ( $\mathrm{PhD}$ diss., European University Institute, 2014), https:// cadmus.eui.eu/handle/1814/33074.

43. Susie Protschky and Tom van den Berge, eds., Modern Times in Southeast Asia, Ig20s-1970s (Leiden: Brill, 2018).

44. Frederick Cooper, Colonialism in Question: Theory, Knowledge, History (Berkeley: California University Press, 2005), 113-49.

45. Vincent Houben, "Representations of Modernity in Colonial Indonesia," in Figurations of Modernity: Global and Local Representations in Comparative Perspective, ed. Vincent Houben and Mona Schrempf (Frankfurt: Campus Verlag, 2008), 23-40.

46. Nobuto Yamamoto, Censorship in Colonial Indonesia, IgoI-I942 (Leiden: Brill, 2019).

47. Benedict Anderson, Imagined Communities: Reflections on the Origin and Spread of Nationalism (London: Verso, 1983), 120-23.

48. While the issue of mixed marriages has received scant attention, various studies have explored topics such as polygamy and concubinage. See Elsbeth Locher-Scholten, "Marriage, Morality and Modernity: The 1937 Debate on Monogamy," Women and the Colonial State: Essays on Gender and Modernity in the Netherlands Indies, 1900-1942 (Amsterdam: Amsterdam University Press, 2000), 187-218; Elizabeth Martyn, The Women's Movement in Post-Colonial Indonesia: Gender and Nation in a New Democracy (New York: Routledge, 2005), 30-52; Cora Vreede-de Stuers, The Indonesian Woman: Struggles and Achievements (The Hague: Mouton, 1960). 
49. Hans Pols, "Notes from Batavia, the Europeans' Graveyard: The Nineteenth-Century Debate on Acclimatization in the Dutch East Indies," Journal of the History of Medicine and Allied Sciences 67, no. I (2012): 120-48.

50. Elsbeth Locher-Scholten, "So Close and Yet So Far: The Ambivalence of Dutch Colonial Rhetoric on Javanese Servants in Indonesia, 1900-1942," in Domesticating the Empire: Race, Gender, and Family Life in French and Dutch Colonialism, ed. Julia Clancy-Smith and Frances Gouda (Charlottesville: University of Virginia Press, 1998), I3I-53; Ann Laura Stoler, "Making Empire Respectable: The Politics of Race and Sexual Morality in 2oth-Century Colonial Cultures," American Ethnologist 16, no. 4 (1989): 634-60; Ann Laura Stoler, Carnal Knowledge and Imperial Power: Race and the Intimate in Colonial Rule (Berkeley: University of California Press, 2002).

51. Freek Colombijn and Joost Coté, eds., Cars, Conduits, and Kampongs: The Modernization of the Indonesian City, 1920-1960 (Leiden: Brill, 2015); Susie Protschky, ed., Photography, Modernity, and the Governed in Late-Colonial Indonesia (Amsterdam: Amsterdam University Press, 2015); Protschky and Van den Berge eds., Modern Times in Southeast Asia.

52. Yulia Nurliani Lukito, "Colonial Exhibition and a Laboratory of Modernity: Hybrid Architecture at Batavia’s Pasar Gambir," Indonesia Ioo (2015): 77-104; Joost Coté, "Staging Modernity: The Semarang International Colonial Exhibition, 1914," Review of Indonesian and Malaysian Affairs 40, no. I (2006): I-44.

53. Henk Schulte Nordholt, "New Urban Middle Classes in Colonial Java: Children of the Colonial State and Ancestors of a Future Nation," BKI I73, no. 4 (2017): 439-4I; Tom Hoogervorst and Henk Schulte Nordholt, "Urban Middle Classes in Colonial Java (1900-1942): Images and Language," BKI 173, no. 4 (2017): 424-74.

\section{Chapter I. Setting the Stage}

I. Kartini, January I2, 1900, in Letters of a Javanese Princess, 29-47.

2. The term "Javanization" was first coined by Benedict Anderson in Language and Power, $133-34$.

3. Van den Doel, De stille macht; Sutherland, The Making of a Bureaucratic Elite; Cees Fasseur, "Cornerstone and Stumbling Block: Racial Classification and the Late Colonial State in Indonesia," in The Late Colonial State in Indonesia: Political and Economical Foundations of the Netherlands Indies, $1880-1942$, ed. Robert B. Cribb (Leiden: KITLV Press, 1994), 31-57; Stoler, Carnal Knowledge.

4. An important exception is Taylor, The Social World of Batavia.

5. A good example is the work of Bernard Cohn, Colonialism and Its Forms of Knowledge.

6. Taylor, The Social World of Batavia; Bosma and Raben, Being "Dutch" in the Indies.

7. Taylor, The Social World of Batavia, xvii-xxii and 33-77.

8. The third princely state was Mangkunagaran. In I8I2, the British broke up Yogyakarta and created Pakualam as the fourth princely state. 
9. M. C. Ricklefs, Jogjakarta under Sultan Mangkubumi, I749-I792: A History of the Division of Java (London: Oxford University Press, 1974), 362-413; M. C. Ricklefs, A History of Modern Indonesia since c. I20o (Stanford, CA: Stanford University Press, 200I), 86-130; Pemberton, On the Subject of "Java", 28-67.

ı. Traditionally, Javanese states were divided administratively into regencies, or kabupaten, directed by a regency head, or bupati (in Dutch, regentschap and regent, respectively). In turn, regencies were divided into districts managed by district heads, or wedana. Village leadership was the third and lowest level of administration. This structure was preserved under the VOC and, later, Dutch colonialism.

Ir. Palmier, "The Javanese Nobility under the Dutch," 197-227; Sutherland, The Making of a Bureaucratic Elite, I-I8; Van Niel, The Emergence of the Modern Indonesian Elite, I-29.

I2. Jan Breman, Mobilizing Labour, 57-94.

13. Heather Sutherland, "Pangreh Pradja: Java’s Indigenous Administrative Corps and its Role in the Last Decades of Dutch Colonial Rule" (PhD diss., Yale University, 1973) 4I.

I4. Wisseman Christie, "Rāja and Rāma," 2I-35; Soemarsaid Moertono, State and Statecraft, 14-24; Anderson, Language and Power, 28.

15. Geertz, Negara, I20.

16. Taylor, The Social World of Batavia, xvii-xxii, 3-32, 39-42, and 56-67.

17. S. Kalff, "Javaansche poesaka," Djåwa: Tijdschrift van het Java-Instituut, 3 (I923), I5I-58.

I8. J. A. van der Chijs, Nederlandsch-Indisch Plakaatboek, I602-I8II 2 (Batavia: Landsdrukkerij, I886), III; 4 (1887), 239-44 and 333-536; Taylor, Social World of Batavia, 38-4I and 66-69; J. Groneman, "Javaansche rangen en pajoengs," Tijdschrift van het Indisch Aardrijkskundig Genootschap, no. 4 (I883), I-I3; J. Groneman, "Een en ander over den Javaanschen adel," $I G$ 8, no. 2 (I886), 880-96.

19. Taylor, The Social World of Batavia, 39-42, 56-57, and 66-67.

20. This was part of a global trend. See C. A. Bayly, The Birth of the Modern World, 1780-1914: Global Connections and Comparisons (Malden: Blackwell Publishers, 2004).

2r. "The Edict on Ceremonial and Etiquette of 28 July 1808 " ("Reglement voor het ceremonieel, in acht te nemen door de residenten bij de hoven te Soerakarta en te Djokjokarta") can be found in J. A. van der Chijs, Plakaatboek, is (1896), 63-65.

22. Peter Carey, The Power of Prophecy: Prince Dipanagara and the End of an Old Order in Java, $1785-1855$ (Leiden: KITLV Press, 2007), 166-68.

23. Carey, The Power of Prophecy, 194-257.

24. Carey, The Power of Prophecy, 26I-365.

25. The colonial civil service was known as the Administration of the Interior (Binnenlands Bestuur in Dutch).

26. Sutherland, The Making of a Bureaucratic Elite, I-I8; Van den Doel, De stille macht, 35-57; Palmier, "The Javanese Nobility under the Dutch," 197-227.

27. H. W. Daendels, Staat der Nederlandsche Oostindische bezittingen onder het bestuur van den gouverneur-generaal Herman Willem Daendels in de Jaren I808-I8II (The Hague: 18I4), 94-99. 
28. Van der Chijs, Plakaatboek is (1896), 63-65, 375-77.

29. Carey, The Power of Prophecy, 170; Peter Carey, Babad Dipanagara: An Account of the Outbreak of the Java War, I825-30: The Surakarta Court Version of the Babad Dipanagara with Translations into English and Indonesian-Malay (Kuala Lumpur: Art Printing Works, 1981), 234-35.

30. Carey, The Power of Prophecy, I7 I; John Pemberton vividly described the politics of seating arrangements during the colonial encounter at the court of Surakarta. See $O n$ the Subject of "Java", 56-57.

31. Carey, The Power of Prophecy, 194-257.

32. Carey, The Power of Prophecy, 26I-365.

33. Daendels divided Java into administrative units headed by prefects. Under Raffles, the number of administrative provinces, now called residencies, were expanded and headed by residents. On Java's restoration to the Netherlands, Raffles's titles remained. Van den Doel, De stille macht, 37-40.

34. Van der Chijs, Plakaatboek, is (1896), I57-83, 292-301.

35. Governor General Daendels to the minister of commerce and colonial affairs, November I2, I808, in S. van Deventer, Bijdragen tot de kennis van het landelijk stelsel op Java, op last van zijne excellentie den minister van kolonien, J. D. Fransen van de Putte, eerste deel: De wording van het stelsel, I (Zaltbommel: J. Noman en Zoon, I865), 22.

36. B. Schrieke, De inlandsche hoofden: rede in tegenwoordigheid van zijne excellentie den gouverneur-generaal van Nederlandsch-Indië uitgesproken bij de 4-jarige herdenking van de stichting der Rechtshoogeschool te Batavia, op 27 October 1928 (Weltevreden: Kolff, 1928).

37. Sutherland, The Making of a Bureaucratic Elite, I-I2; Van der Chijs, Plakaatboek, I5 (1896), I57-83.

38. Thomas Stamford Raffles, The History of Java, vol. I (London: John Murray, 1817), 309 .

39. Raffles, The History of Java, vol. I, 310.

40. Raffles, The History of Java, vol. I, 309 .

4I. "Minute recorded by the Honourable Lieutenant-Governor of Java, on the I th June I813," in Thomas Stamford Raffles, Substance of a minute recorded by the Honourable Thomas Stamford Raffles, Lieutenant-Governor of Java and its Dependencies, on the IIth February I8I4; on the introduction of an improved system of internal management and the establishment of a land rental on the island of Java: to which are added several of the most interesting documents therein referred to (London: Black, Parry, and Co., I8I 4), 253-78.

42. The Malay Peninsula was excluded from this agreement, and the resulting diplomatic tension was resolved with the Treaty of London of 1824. Raffles's disappointment in losing Java led him to establish Singapore in I8I9.

43. Th. Stevens, "Van der Capellen's koloniale ambitie op Java: economisch beleid in een stagnerende conjunctuur 1816-1826" (Amsterdam: Historisch Seminarium van de Universiteit van Amsterdam, 1982). 
44. Governor General G. A. G. P. baron van der Capellen to minister of public education, National Industry and Colonial Affairs Anton Reinhard Falck, 9 May I820, Tijdschrift voor Nederlandsch-Indie TNI, 3, no. I (1865), I14-17.

45. Van der Capellen to Falck, May 9, I820, in TNI, 3 (1865), II5.

46. Staatsblad van Nederlandsch-Indië, no. 22 (1820), 98-110.

47. Staatsblad, no. I3 (1824), II-I3; Sutherland, The Making of a Bureaucratic Elite.

48. Staatsblad, no. 22 (1820), $98-110$.

49. Beautiful colored drawings of the payung hierarchies of Yogyakarta (ca. 1900), Surakarta (1869), and Mangkunegaran (I869) can be found in UBL, Special Collections, Collection KITLV, ${ }_{37} \mathrm{~B}_{42-37} \mathrm{~B}_{14} 8$.

50. L. Th. Mayer, Een blik in het Javaansche volksleven, 2 (Leiden: Brill, I897), 509ıо; J. J. Verwijk, "Nota over de staatsie en het gevolg der Inlandsche ambtenaren in de gouvernementslanden op Java en Madoera," TBB, I7 (I899), 45I-6I; "Pajoengs of songsongs, adat en titels," Het Koloniaal Weekblad, 3, no. 33 (1903); J. Groneman, "Een pajoeng-kwestie," TBB, 25 (1903), 38-47; J. E. Jasper, "Staatstie, gevolg en songsongs van Inlandsche ambtenaren in de gouvernementslanden op Java en Madoera," TBB, 27, no. I (I904), I-73.

51. Raffles, A History of Java, vol. I, 308-I2; P. J. Veth, Java: geographisch, ethnologisch, historisch, vol. 4 (Haarlem: De Erven F. Bohn, 1907), 367-68.

52. Carey, The Power of Prophecy, 588-89 and 617-55; Michael Adas, Prophets of Rebellion: Millenarian Protest Movements against the European Colonial Order (Chapel Hill: The University of North Carolina Press, 1979), 3-19, 93-99.

53. Carey, Babad Dipanagara, 234-35.

54. Carey, The Power of Prophecy, 588-89 and 617-55.

55. This is depicted in a manuscript image that shows Diponegoro seated on his horse accompanied by his gilded payung during the battle of Tegelrejo on July 20, I825. Peter Carey, Sisi lain Diponegoro: babad kedung kebo dan historiografi perang (Jakarta: Gramedia, 2017); Pandji Kuda Waneng Pati Klayan Klana Tunjung Seta, I860, D Or. 17, Collection KITLV, Special Collections, UBL.

56. Carey, The Power of Prophecy, 586; P. J. F. Louw, De Java-Oorlog van $1825-1830$, vol. 2 (Batavia: Landsdrukkerij, I897), 244.

57. "Gouvernements Besluit van den 2isten December i827 No. I5," TNI, I (I865), I26. 58. Van der Capellen to Falck, May 9, I820, TNI, 3 (1865), II5.

59. Anderson, Language and Power, 133-34.

6o. "Advies van den Luitenant-Generaal Van Den Bosch over het stelsel van kolonisatie," in D. C. Steijn Parve, Het koloniaal monopoliestelsel getoetst aan geschiedenis en staathuiskunde (Zaltbommel: Joh. Noman en Zoon, I851), 294-328; R. E. Elson, Village Java under the Cultivation System, I830-1870 (Sydney: Allen and Unwin, 1994); C. Fasseur, The Politics of Colonial Exploitation: Java, the Dutch and the Cultivation System, translated by R. E. Elson (Ithaca: SEAP, Cornell University Press, 1992).

6I. C. W. Margadant, Het Regeeringsreglement van Nederlandsch-Indië, vol. I-3 (Batavia: G. Kolff \& Co., I894-7); Staatsblad, no. 2 (1855). 
62. Van den Bosch to Baud, January 31, 1831, in Briefwisselingtussen J. van den Bosch en J. C. Baud, $1829-1832$ en $1834-1836$. Eerste deel: brieven van den Bosch (Utrecht: Kemink en zoon N. V., 1956), 74.

63. Van den Bosch to Baud, June 4, I831 and August 7, 1832, in Briefwisseling, vol. I, 93, and I58; J. van den Bosch, Mijne verrigtingen in Indië: verslag van z. excellentie den Commissaris Generaal J. van den Bosch, over de jaren 1830, 1831, 1832, en 1833. (Amsterdam: Frederik Muller, 1864), 398-402; Elson, Village Java, 179-84.

64. Heather Sutherland dubbed the rule of Daendels and Raffles the "nadir" of the bupati in The Making of a Bureaucratic Elite, I2-16; Elson, Village Java, I80-86; Van den Doel, De stille macht, 59-65; Palmier, "The Javanese Nobility under the Dutch," 202, 214-18.

65. Van Niel, The Emergence of the Modern Indonesian Elite, 26.

66. Kees Groeneboer, Gateway to the West; Staatsblad, no. 34 (1827), no. 109 (1827); Cees Fasseur, De Indologen: ambtenaren voor de Oost I825-1950 (Amsterdam: Aula, 2003), $25-28$.

67. Cees Fasseur, "De taal is gans de Indisch ambtenaar. De taalopleiding van de bestuursambtenaren," in Kees Groeneboer (ed.), Koloniale taalpolitiek in Oost en West: Nederlands-Indië, Suriname, Nederlandse Antillen en Aruba (Amsterdam: Amsterdam University Press, 1997), I87-206.

68. J. C. Baud's report to King William I, June 28, 1842, in Historische nota over het vraagstuk van de opleiding en benoembaarheid voor den administratieven dienst (Batavia, Landsdrukkerij, 1900) 23. The English translation comes from Kees Groeneboer, Gateway to the West, 74.

69. Fasseur, De Indologen, 55-76, 90-97.

70. Sembah denotes worship, homage, or deference, but it also refers to the particular gesture of respect as described in the text. Jongkok refers to both static and active forms of crouching and was used interchangeably by contemporaries. When joined together, sembah-jongkok was used to signify the general culture of deference etiquette guiding social interactions and expressing social hierarchies. Anderson, Language and Power, 123-51 and 194-237. For Raffles's description, see Raffles, A History of Java, vol. I, 308-10.

7I. "Geen Europeesche kangdjengs meer," De Indiër, I, no. 35 (June I8, I9I4), I20.

72. Susie Protschky, "The Colonial Table: Food, Culture and Dutch Identity in Colonial Indonesia," Australian Journal of Politics and History, 54, no. 3 (2008), 34657; Onghokham, The Thugs, the Curtain Thief, and the Sugar Lord: Power, Politics, and Culture in Colonial Java (Jakarta: Metafor Publishing, 2003), 31I-22; D. C. M. Bauduin, Het Indische leven (The Hague: H. P. Leopold, I94I), 84-87; Louis Couperus, The Hidden Force, trans. E. M. Beekman (Amherst: University of Massachusetts Press, I985), IоI.

73. V. I. van de Wall, Oude Hollandsche bouwkunst in Indonesië (Antwerpen: De Sikkel, 1942); Cor Passchier, "Colonial Architecture in Indonesia: References and Developments," The Past in the Present: Architecture in Indonesia, ed. Peter J. M. Nas, 97-II2. 
74. Elson, Village Java, 84-85.

75. The hipped roof was an Austronesian (a language group covering most of maritime Southeast Asia and the Pacific) characteristic.

76. Ranked from least to most prestigious, the roof styles are known as kampung, limasan, and joglo.

77. Cor Passchier, "Colonial Architecture in Indonesia," 97-II2; Van de Wall, Oude Hollandsche, 10-I2 and 29-32; Huib Akihary, Architectuur \& stedebouw in Indonesië, I870-1970 (Zutphen: De Walburg Pers, 1990), I 4-I5.

78. Passchier, "Colonial Architecture in Indonesia," 97-II2; Abidin Kusno, "The Afterlife of the Empire Style: Indische Architectuur and Art Deco," The Past in the Present, 13I-46.

79. Taylor, The Social World of Batavia, 52-77; Jean Gelman Taylor, "Costume and Gender in Colonial Java, 1800-1940," in Outward Appearances, ed. Henk Schulte Nordholt, 85-116; Inger McCabe Elliot, Batik: Fabled Cloth of Java (Singapore: Periplus Editions, 2004), I12-15.

80. McCabe Elliot, Batik, 36, 68-69; Taylor, "Costume and Gender," 9I-94.

81. Harmen C. Veldhuisen, Batik Belanda 1840-1940: Dutch Influence in Batik from Java, History and Stories (Jakarta: PT. Gaya Favorit, 1993).

82. McCabe Elliot, Batik, 32; Dorine Bronkhorst and Esther Wils, Tropenecht: Indische en Europese kleding in Nederlands-Indië (The Hague: Stichting Tong, 1996).

83. Bart Luttikhuis, "Beyond Race: Constructions of 'Europeanness' in Late-Colonial Legal Practice in the Dutch East Indies, European Review of History, 20, no. 4 (2013), 539-58; Margadant, Regeeringsreglement; Fasseur, "Cornerstone and Stumbling Block," 31-57; A. van Marle, "De groep der Europeanen in Nederlands-Indie: iets over ontstaan en groei," Indonesië, 5 (1951-52), 97-99.

84. Staatsblad, no. 8 (1829, 2I-30.

85. Staatsblad, no. 4 and 59 (I849), no. 26 (I851), no. IIo and III (I872).

86. Fasseur, The Politics of Colonial Exploitation, $117-19$.

87. The declaration of the Agrarian and Sugar Laws in 1870 opened Java up for private enterprise. Staatsblad, no. 55 and 117 (1870). Elson, Village Java, I28-52.

88. This perception was popularized in Multatuli's influential novel, Max Havelaar, which was considered the nail in the coffin for the Cultivation System. The novel's negative view of the Javanese aristocracy deliberately overlooked the critical role played by Dutch officials, who suddenly acted as protectors of the colonized, at least rhetorically if not in reality. Multatuli, Max Havelaar: Or, the Coffee Auctions of a Dutch Trading Company, trans. Roy Edwards (New York: Penguin Books, 1987).

89. Staatsblad, no. I22, I23, and 125 (1867); Elson, Village Java, I48; Van den Doel, De stille macht, 107-56.

90. Staatsblad, no. 53 (1867).

91. Van den Doel, De stille macht, 80-104; Sutherland, The Making of a Bureaucratic Elite, 35-43.

92. Van Niel, The Emergence of the Modern Indonesian Elite, 23-29; J. A. A. van Doorn, De laatste eeuw van Indie: ontwikkeling en ondergang van een koloniaal project 
(Amsterdam: Bert Bakker, 1994), 31-35; Liesbeth Hesselink, Healers on the Colonial Market: Native Doctors and Midwives in the Dutch East Indies (Leiden: KITLV Press, 2011).

93. Jasper, "Staatstie, gevolg en songsongs," I-73; For pawnshop personnel, see Staatsblad, no. 393 (1906); Palmier, Social Status and Power in Java, 35; Liesbeth Hesselink, "The Unbearable Absence of Parasols: The Formidable Weight of a Colonial Java Status Symbol," IIAS Newsletter, no. 45 (2007), 26.

94. Van den Doel, De stille macht, 80-104.

95. George Murray Reith, A Padre in Partibus: Being Notes and Impressions of a Brief Holiday Tour through Java, the Eastern Archipelago and Siam (Singapore: Singapore and Straits Print. Office, 1897), I88-90.

96. Christiaan Snouck Hurgronje, "De Inlandsche bestuursambtenaren, vooral op Java," De Gids, 72 (1908), 220.

97. Benedict Anderson, Mythology and the Tolerance of the Javanese (Ithaca: SEAP, Cornell University Press, 1965); Sears, Shadows of Empire.

98. Schulte Nordholt, The Spell of Power, 7.

99. Corporal punishment, intimidation, and surveillance were intrinsic features of the Cultivation System. Official reports deliberately described peasant resistance-in the form of foot-dragging, flight, and sectarian withdrawal-as sporadic and small-scale as to not undercut the image of the docile Javanese. Breman, Mobilizing Labour, 26770; Michael Adas, "From Footdragging to Flight." 64-86.

I00. Kartini, January I2, 1900, 42.

\section{Chapter 2. "Sweet Was the Dream, Bitter the Awakening"}

I. Goenawan Mangoenkoesoemo, “De Javaan en zijn hormatgebruiken,” Java Bode (May 22, 1905). The article also appeared in Bintang Hindia, 3, no. I 4 (1905): 166.

2. Mangoenkoesoemo, "De Javaan en zijn hormatgebruiken."

3. Michael Adas, "Contested Hegemony: The Great War and the Afro-Asian Assault on the Civilizing Mission Ideology," Journal of World History I5, no. I (2004): 3I-63; Locher-Scholten, Ethiek in fragmenten; Luttikhuis, "Negotiating Modernity," I-32.

4. Van Niel, The Emergence of the Modern Indonesian Elite, 15-30; Hans Pols, Nurturing Indonesia: Medicine and Decolonization in the Dutch East Indies (Cambridge: Cambridge University Press, 2018), I-20.

5. Goenawan Mangoenkoesoemo, "De geboorte van Boedi-Oetomo," in Soembangsih: gedenkboek Boedi-Oetomo 1908 20 Mei I9I8 (Amsterdam: DrukkerijJ. Tjabring, 1918), I0.

6. D. A. Rinkes, "Oude en nieuwe stroomingen onder de bevolking," Indisch Genootschap: Verslagen der Algemene Vergaderingen (November 18, 1916): 55-78.

7. Scott, Dominance and the Arts of Resistance, I-I6.

8. Van Niel, The Emergence of the Modern Indonesian Elite, 46-72.

9. For a detailed study of these companies (among others) and their cultural significance in the history of empire, see Kris Alexanderson, Subversive Seas: Anticolonial 
Networks across the Twentieth-Century Dutch Empire (Cambridge: Cambridge University Press, 2019).

Io. Ravestijn and Kop (eds.), For Profit and Prosperity; Moon, Technology and Ethical Idealism; Herman Burgers, De garoeda en de ooievaar: Indonesië van kolonie tot nationale staat (Leiden: KITLV Press, 20II), I00-IO3. On technology and empire more generally, see Daniel R. Headrick, The Tools of Empire: Technology and European Imperialism in the Nineteenth Century (New York: Oxford University Press, 198I).

ir. Elsbeth Locher-Scholten, "Summer Dresses and Canned Food: European Women and Western Lifestyles in the Indies, 1900-1942," in Outward Appearances: Dressing State and Society in Indonesia, ed. Henk Schulte Nordholt (Leiden: KITLV Press, I997), I5I-80.

I2. J. A. A. van Doorn, Indische Lessen: Nederland en de koloniale ervaring (Amsterdam: Bert Bakker, 1995) 34.

13. Sysling, Racial Science; Gouda, Dutch Culture Overseas, I2 I-27.

I 4. Gouda, Dutch Culture Overseas, I49-54; Stoler, "Making Empire Respectable," 645-46. Christiaan Eijkman, Over gezondheid en ziekte in heete gewesten (Utrecht: J. van Druten, I898).

15. Benedict Anderson referred to this as an idealized "Tropical Gothic" in Imagined Communities, I5I.

16. Van Doorn, De laatste eeuw van Indië, 23-46; Burgers, De garoeda en de ooievaar, $100-103$.

17. Census of 1930 in the Netherlands Indies, vol. 8 (Batavia: Landsdrukkerij, 1936) 84-86.

I8. Van Marle, "De groep der Europeanen," 32 I.

19. Stoler, Carnal Knowledge, 79-16r; Frances Gouda, "Nyonyas' on the Colonial Divide: White Women in the Dutch East Indies, 1900-1942," Gender \& History 5, no. 3 (1993): 318-42; Locher-Scholten, Women and the Colonial State, 19.

20. C. Th. van Deventer, "Een eereschuld," De Gids 63, no. 2 (1899): 205-57; P. Brooshooft, De ethische koers in de koloniale politiek (Amsterdam: J. H. de Bussy, 1901).

21. Locher-Scholten, Ethiek in fragmenten; Kuitenbrouwer, The Netherlands and the Rise of Modern Imperialism; H. L. Wesseling, "Bestond er een Nederlands imperialisme?" Tijdschrift voor Geschiedenis 99, no. 2 (1986): 214-25.

22. Alice L. Conklin, A Mission to Civilize: The Republican Idea of Empire in France and West Africa, I895-1930 (Stanford: Stanford University Press, 1997); Ballantyne and Burton, Empires and the Reach of the Global.

23. The vernacular press often referenced the French, Russian, and Filipino revolutions as models to emulate. For instance, see Padjadjaran, October II, 1920, Overzicht van de Inlandsche en Maleisisch-Chineesche Pers (IPO), no. 43 (1920). Others suggested that the Netherlands should follow the US example in the Philippines, see Darmo Kondo, May 3, 1919, IPO, no. I8 (1919). Anne Foster, Projections of Power: The United States and Europe in Colonial Southeast Asia, I9I9-194I (Durham: Duke University Press, 2010).

24. P. H. Fromberg, De Chineesche beweging op Java (Amsterdam: Elsevier, I911); P. Tjiook-Liem, De rechtspositie der Chinezen. 
25. Van Dijk, The Netherlands Indies and the Great War, 19-90; Ahmat Adam, The Vernacular Press, 79-107; Van der Meer, "Igniting Change in Colonial Indonesia," 50I-32.

26. For instance, in 1848 a school was established that trained scribes and administrators, followed in $185 \mathrm{I}$ by a school for indigenous doctors (dokter djawa), in 1852 by a teacher training school, in 1879 by a school for "Native Heads" (Hoofdenscholen) for training prominent priyayi children to be administrators, and in 1893 by the First and Second Class Native Schools. Van Niel, The Emergence of the Modern Indonesian Elite, $15-30$.

27. Van Niel, The Emergence of the Modern Indonesian Elite, 3I-100.

28. Schulte Nordholt, "New Urban Middle Classes in Colonial Java," 439-4I; Hoogervorst and Schulte Nordholt, "Urban Middle Classes in Colonial Java," 424-74. 29. Shiraishi, An Age in Motion," 26-27.

30. The most prominent associations with a predominantly culturally Javanese outlook were Boedi Oetomo (f. 1908), the Committee for Javanese Nationalism (f. 1919), and Taman Siswa (f. 1922). Those with a distinctly religious outlook were the Sarekat Islam (f. I9I2), Muhammadiyah (f. I912), and Nahdlatul Ulama (f. 1926). Those with an ideological basis were the Indische Partij (f. I9I2), the Indische Sociaal-Democratische Vereenging (f. 1914), its successor Perserikatan Kommunis di Hindia (f. 1920), which changed its name to Partai Kommunis Indonesia in 1924. And finally, those with a secular perspective were the Indische Party (f. 1912) and Partai Nasional Indonesia (f. 1927). Elson, The Idea of Indonesia, I-97.

31. William O'Malley, "Second Thoughts on Indonesian Nationalism," Indonesia: Australian Perspectives (1980): 60I-13.

32. Anderson, Language and Power, 194-237; Raffles, A History of Java, vol. I, 308-12.

33. Snouck Hurgronje to the Director of the European Administration of the Interior, April 20, 1904, in Ambtelijke adviezen van C. Snouck Hurgronje 1889-1936, vol. I, ed. E. Gobée and C. Adriaanse (1957), 518-25; Sutherland, The Making of a Bureaucratic Elite, 24-25.

34. A. H. J. G. Walbeehm, "Het leven van den bestuursambtenaar in het binnenland," Onze Koloniën I, no. 3 (1913).

35. Anderson, Language and Power, $13 \mathrm{I}-32$.

36. Hazeu to the Committee Mangajoe Basa Djawa, December 6, I918, in Collection Hazeu, $\mathrm{H}$ 1083, no. 29, UBL.

37. Groeneboer, Gateway to the West, 6-7.

38. Bijblad op het Staatsblad van Nederlandsch-Indië, no. 6496 (1907).

39. Kartini to Mejuffrouw Zeehandelaar, January I2, 1900, in Letters of a Javanese Princess, 40-42.

40. "Nota betreffende de verhouding tusschen het Europeesch en het inlandsch bestuur," IG II, no. 2 (I889): I52I-24.

4I. Hadi Ningrat, "De achteruitgang van het prestige der inlandsche hoofden en de middelen om daarin verbetering te brengen," TBB, I7 (1899): 367-385. 
42. Eckart [pseudonym of H. E. Steinmetz], Indische brieven aan een staatsraad (Haarlem: De Erven F. Bohn, I888), I8I-82.

43. Eckart, Indische brieven, $18 \mathrm{I}-82$.

44. Laffan, The Makings of Indonesian Islam, 190-208; Van den Doel, De Stille Macht, I8I-82.

45. Snouck Hurgronje to the Director of Education, Religion, and Industry, September 10, 1896; Snouck Hurgronje to the Director of the Administration of the Interior, March 13, 1902; both in Ambtelijke adviezen, vol. 2, 1019-27.

46. Snouck Hurgronje to Governor General Roosenboom, August 16, 1903, in Ambtelijke adviezen, vol. 2, 1027-28.

47. Bijblad, no. 5946 (1904).

48. As president of the Diminished Welfare Committee, Steinmentz ensured that his view on the matter of hormat was included in its reports. Chair of the Welfare Committee Steinmetz to Governor General Idenburg, September 30, 1914, in Onderzoek naar de Mindere Welvaart, vol. I2, I-5.

49. Snouck Hurgronje to the Director of the Administration of the Interior, May 26, 1904, Ambtelijke adviezen 2, $1028-35$.

50. Van Heutsz was rewarded the highest office in Java for his pacification (brutal repression) of Aceh in northern Sumatra. The colonial campaign against the Acehnese lasted more than three decades (1873-1904) and was decided in part by Hurgronje's insights on Acehnese culture and society. Adrian Vickers, A History of Modern Indonesia (Cambridge: Cambridge University Press, 2005), 10-13.

51. Bijblad, no. 6118 (1905). The payung circular was dated November 3, 1904, but not published in the Bijblad.

52. Van Heutsz to the Minister of Colonial Affairs Idenburg, March 13, 1905, Collection A. W. F. Idenburg, inventory no. I29, HDC.

53. Bijblad, no. 6118 (1905).

54. Bijblad, no. 6ris.

55. Snouck Hurgronje to the Director of the Administration of the Interior, April 20, 1904, Ambtelijke adviezen I, 525.

56. See the editorial of M. van Geuns in Soerabaiasch Handelsblad, November 26, 1904.

57. See the editorial of T. Vierhout in De Locomotief, November 26, 1904.

58. Karel Wybrands, "Een idealist-practicus," NNI, November 30, 1904; "Hormat," $I G$ 27, no. I (1905): 265-66.

59. "Nog even iets over de pajoengs," NNI, December 6, I904; "De pajoeng," NNI, January I9 and 21, 1905. "Hormat," $I G, 27$, no. I (1905): 43I-33.

6o. Achmad Djajadiningrat, Herinneringen van Pangeran Aria Achmad Djajadiningrat (Batavia: Kolff, 1936), 224-26.

6I. "Eens residenten afscheid aan zijn pajong," NNI, December 3, 1904.

62. "Eens residenten afscheid aan zijn pajong."

63. Idenburg to Van Heutsz, February 14, 1905, in Collection J. B. Van Heutsz, inventory no. 2, 2.21.008.79, NL-HaNA. 
64. Idenburg succeeded Van Heutsz as governor general in 1909 and continued his struggle to implement a more ethical foundation of colonial authority. Van Heutsz to Idenburg, March 13, 1905, in Collection A. W. F. Idenburg, box 13, inventory no. 129 , HDC.

65. Snouck Hurgronje to Van Heutsz, March I, 1906, in Ambtelijke adviezen, vol. 2, $1037-38$.

66. Bijblad, no. 6496 (1907).

67. Bijblad, no. 6496.

68. Karel Wybrands, "Regeerings-beleid en regeerings-organen." NNI, April 23, 1906; "Een tweede hormat-circulaire," $I G$ 28, no. 2 (I906): IIOI-2.

69. Henri Borel, “Ambtenaar," WVI 4, no. I 4, July 28, 1907, 269-71; A. Muhlenfeld, "Iets over de naleving der voorschriften in bijblad 6061, 6ir8 en 6496," TBB 35 (1908), 33-39.

70. Carlo [pseudonym], "Indische indrukken XXIV," WVI 3, no. I4, July 29, I906, 30I-4.

71. Van Heutsz to the Director of the European Civil Service, January 20, 1909, in Collection Hazeu, $\mathrm{H}$ 1083, folder 17 , no. Io, UBL. The abuses were reported in the Bataviaasch Nieuwsblad, December 30, 1908.

72. Like Javanese, the Sundanese language has distinct hierarchical levels.

73. Hazeu to Van Heutsz, March II, 1909, in Collection Hazeu, H I083, folder 17, no. Io, UBL.

74. Bijblad, no. 7029 (1910).

75. Gonggrijp to Van Heutsz, April 27, 1909, Collection Hazeu, H I083, folder 17, no. Io, UBL.

76. Boissevain to Van Heutsz, April 30, 1909, in Collection Hazeu, $\mathrm{H}_{1083}$, folder I7, no. Iо, UBL.

77. Pantjaran Warta, January I8, 1912, KT I (1912): 229-30. Similar arguments can be found in Pewarta Deli, May 31, 1912, KT I (1912): 837-38 and Medan Prijaji, August I, I9I2, $K T$, I (1912): I222.

78. Bintang Soerabaja, April 30, 1912.

79. Abdoel Rivai, "Bangsawan pikiran," Bintang Hindia O, no. I (1902): 3-4; Abdoel Rivai, "Kaoem moeda," Bintang Hindia 3, no. I4 (1905): 159-6I; Adam, The Vernacular Press, $138-40$; Pols, Nurturing Indonesia, $2 \mathrm{I}-45$.

8०. Goenawan Mangoenkoesoemo, "Iets over den Javaan en zijn hormatgebruiken," Java Bode, June 22, 1905.

8I. Mangoenkoesoemo, "Iets over den Javaan en zijn hormatgebruiken."

82. Wongso [pseudonym], "Schetsen uit het Javaansche volksleven," NNI, June 5 and 6,1905.

83. Goenawan Mangoenkoesoemo, "De tijden veranderen en wij met hen," Java Bode, June 23, 1905.

84. Mangoenkoesoemo, "De tijden veranderen en wij met hen."

85. Wongso, "Schetsen uit het Javaansche volksleven." 
86. “De Javaan en zijn hormat-gebruiken," Bintang Hindia 3, no. I4 (1905): I66; “Nog eens: De Javaan en zijn hormat-gebruiken," Bintang Hindia 3, no. I5 and I6 (1905): 178 and 190-9I. Rivai's commentary was published as introduction to these articles.

87. The Bintang Hindia was published between 1902 and 1907. By the end of 1904, it had a circulation of twenty-seven thousand, meaning its readership must have been even higher. Harry A. Poeze, "Early Indonesian Emancipation: Abdul Rivai, Van Heutz, and the Bintang Hindia," BKI I45, no. I (1989): 87-106; Adam, The Vernacular Press, 98-106; Nagazumi, The Dawn of Indonesian Nationalism, 26-65.

88. Rivai, "Kaoem moeda," I59-6I.

89. "Kehormatan," Bintang Hindia I, no. 4 (1903): 38-39; "Hormat," Bintang Hindia I, no. 4 (1903): 39. Similar descriptive and uncritical publications can be found elsewhere before 1904. For instance, "Tjara Djawa dan hoeboengannja," Taman Pengadjar, October 15, I899, I13-16. "Hormat," Taman Pengadjar, February I5, 1900, 225-26.

90. Kertowinoto, "Sembah dan jongkok," Bintang Hindia 3, no. 3 (1905): 38-39; Karno, "Hormat dan percaja," Bintang Hindia 3, no. 7 (1905): 75-77.

91. Ronggo, "Hormat," Bintang Hindia 3, no. 7 (1905): 74-75. For similar activist articles see "Adat roepa-roepa bangsa: memberi salam dan hal 'hormat circulair," Taman Pengadjar, January 15, 1905, 217-2I; "Kemajoean bangsa Djawa," Taman Pengadjar, August I5, 1905, 55-6I.

92. S., "Suka akan kehormatan," Bintang Hindia 4, no. 6 (1906): 200-204.

93. S., "Suka akan kehormatan," 200-204.

94. Pemberita Betawi, January 17, 1912, KT I (1912): 219.

95. Sinar Djawa, December 2, I9II, $K T_{\text {I }}$ (I9II): 102.

96. Pemberita Betawi, March 31, 1913, KT 2 (1913): 1029.

97. Nagazumi, The Dawn of Indonesian Nationalism, 26-50. Kartodirdjo, Pengantar Sejarah Indonesia baru, 99-106. Adam, The Vernacular Press, 79-107. Van Niel, The Emergence of the Modern Indonesian Elite, 56-62.

98. Mangoekoesoemo, "De geboorte van Boedi-Oetomo," 9-1 4; Mangoenkoesoemo, "De Javaan en zijn hormatgebruiken."

99. Idenburg to Van Kol, July 7, 1913, in De Opkomst van de nationalistische beweging in Nederlandsch-Indie: Een bronnenpublicatie, ed. S. L. van der Wal (Groningen: J. B. Wolters, 1967), 297-98.

ıоo. Hazeu to Van Heutsz, December 30, 1908, in Collection Hazeu, H 1083 , no. 24 , UBL.

\section{Chapter 3. Disrupting the Colonial Performance}

I. Descriptions of the encounter can be found in Advisor for Native Affairs G. A. J. Hazeu to Governor General A. W. F. Idenburg, August 18, 1913, in Collection Hazeu, H ıo83, no. 29, UBL; Jaksa Raden Soemarsono to Resident H. Rijfsnijder, June 8, 1913, 
Archive Ministerie van Koloniën: Openbaar Verbaal, I90I-1952, 2.10.36.04, I076, Verbaal (Vb.) August 22, 1913, NL-HaNA.

2. P. H. Fromberg, "De Inlandsche beweging op Java," De Gids 78 (1914): 28-29.

3. Shiraishi, An Age in Motion, xi-xvi, 4I-II6.

4. L. W. C. van den Berg, De Inlandsche rangen en titels op Java en Madoera (Landsdrukkerij; Batavia, I887).

5. Rijfsnijder to Idenburg, May I0, 1913, in Archive Ministerie van Koloniën: Geheim Archief, I90I-1940, 2.10.36.5I, I53, Vb. August 9, 1913, BI3, NL-HaNA; Heather Sutherland, "The Priyayi," Indonesia I9 (1975): 58.

6. On completion of his secondary education at the Gymnasium Willem III, Soemarsono enrolled in a three-year civil service training program known as the Afdeeling B at the same institution. After the first year, he opted out of his studies and began his civil service career. Graduation information was published in NNI, April 30 , I901, May 10, 1902, May 6, I903, and May 8, 1905.

7. Hazeu to Idenburg, August 18, 1913, UBL.

8. Soemarsono to Rijfsnijder, June 8, I913, NL-HaNA.

9. Soemarsono to Rijfsnijder, June 8, 1913, NL-HaNA.

Io. Assistant Resident J. C. Bedding to Rijfsnijder, April 21, I913 and May 13, I913, in Koloniën: Geheim Archief, 2.10.36.51, 153, Vb. August 9, 1913, Bı3, NL-HaNA.

II. Soemarsono to Rijfsnijder, June 8, 1913, NL-HaNA.

I2. Rijfsnijder to Idenburg, May IO and 23, I913; Bedding to Rijfsnijder, April 21, 19I3, May I3 and 19, 1913, in Koloniën: Geheim Archief, 2.10.36.51, 153, Vb. August 9, 1913, $\mathrm{B}_{13}$, NL-HaNA. Soewardi Soerjaningrat, "Staat de regeering werkelijk sympathiek tegenover de S.I.?,” De Indiër I, no. 4 (November 13, 1913): 48.

13. Boedi Oetomo was founded on May 20, 1908.

I4. Witness accounts of Kartakoesoema and Koesoemadipoera, May 29, 1913; Bedding to Rijfsnijder, June I, I913, in Koloniën: Openbaar Verbaal, 2.10.36.04, I076, Vb. August 22, 1913, NL-HaNA.

15. "Gisting," NNI, June 2, I913.

16. Bedding to Rijfsnijder, June I, 1913, NL-HaNA.

17. Rijfsnijder to Idenburg, June I2, I913; Idenburg to Rijfsnijder, June I7, I9I3, Koloniën: Openbaar Verbaal, 2.10.36.04, 1076, Vb. August 22, 1913, NL-HaNA.

18. Idenburg to Minister of Colonial Affairs T. B. Pleyte, July 2, I913; "Extract uit het register der besluiten van den Gouverneur-Generaal van Nederlandsch-Indië," June 30, 1913, in Koloniën: Geheim Archief, 2.10.36.5I, 153, Vb. August 9, I9I3, $\mathrm{B}_{13}$, NL-HaNA.

19. Soemarsono to Hazeu, July 28, 1913, in Collection Hazeu, H I083, no. 29, UBL. 20. Soemarsono to Hazeu, July 28, I913, NL-HaNA; Hazeu to Idenburg, July II, I9I3, in De opkomst van de nationalistische beweging, 299-30I.

21. Soewardi Soerjaningrat, Djika saja Nederlander,. . . / Als ik eens Nederlander was,... (Bandung: Comité Boemipoetra, 1913).

22. Idenburg to Rijfsnijder, August 22, 1913, in Collection Hazeu, H I083, no. 29, UBL. 23. Soemarsono to Hazeu, August 17, 1913, in Collection Hazeu, H Io83, no. 29, UBL. 
24. Hazeu to Idenburg, August I8, 1913, in Collection Hazeu, H I083, no. 29, UBL. 25. Bedding to Wirasaputra, July 7, 1913, in Collection Hazeu, H I083, no. 29, UBL. 26. Soemarsono to Hazeu, August 17, 1913, UBL.

27. Soemarsono to Hazeu, August 17, 1913, UBL.

28. Hazeu to Idenburg, August 20, 1913, in Collection Hazeu, H 1083, no. 29, UBL. 29. Idenburg to Rijfsnijder, August 22, I913; Idenburg to the Director of Department of Justice, August 22, 1922, in Collection Hazeu, H 1083, no. 29, UBL.

30. Bijblad, no. 7939 (1914).

3r. In places the document's language was identical to that in Hazeu's correspondence about Soemarsono's case. "Nota bij de hormatcirculaire van 22 augustus 1913," in Collection Hazeu, $\mathrm{H}_{1083}$, no. 57, UBL.

32. W. T. L. Boissevain, "Protestbeweging van de vereeniging van ambtenaren bij het binnenlandsch bestuur," $K T_{3}$, no. I (1914): 69-78; "De zevende hormat-circulaire en de uitlatingen van Dr. Rinkes," $K T_{3}$, no. I (1914): 365-67; Tertius, "Geef acht, B. B.!," $K T_{3}$, no. I (1914): 376-80; G. Th. Stibbe, "Nog een protest," $K T_{3}$, no. I (1914): 493-95.

33. Hazeu to Soemarsono, August 22, 1913, in Collection Hazeu, H Io83, no. 29, UBL. 34. Soemarsono to Hazeu, September 5, 1913, in Collection Hazeu, H Io83, no. 29, UBL.

35. The Purwakarta Sarekat Islam was legally recognized on April 20, 1915. For the deliberations leading up to this decision, see Rijfsnijder to Bedding, September 30, 1913; Bedding to Rijfsnijder, October 27, 1913; Rijfsnijder to Idenburg, November 4, 1913; Advisor for Native Affairs D. A. Rinkes to Idenburg, February 13, I914; "Extract uit het register der besluiten van den Gouverneur-Generaal van Nederlansch-Indië, Buitenzorg, 20 april 1915, no. 43," in Koloniën: Openbaar Verbaal, 2.10.36.04, 1517, Vb. March 8, I916, NL-HaNA.

36. Rinkes to Tjokjroaminoto, October 25, 1913, in De opkomst van de nationalistische beweging: 346-53.

37. Oetoesan Hindia, nos. 233-34 and 24, Djawa Tengah, no. 7, and Kaoem Moeda, no. 50-51, KT 3 (1913): 388, 519, 526, and 805. “Constitutievergadering S. I.," De Indiër I no. 28 (April 30, 1914): 31-32. Bataviaasch Nieuwsblad, March 19, I9I4.

38. Oetoesan Hindia, no. 212, $K_{4}$ (1914): 242.

39. Pantjaran Warta, no. 75, $\mathrm{KT}_{3}$ (1913): 804-5; Bescheiden betreffende de vereeniging "Sarekat Islam" (Batavia: Landsdrukkerij, 1913), 21.

40. Sarekat-Islam congres (1916): 58; (1918): 65; (1919): I4-I5 and I13-I4.

41. Laffan, Islamic Nationhood, 77-102.

42. Sarekat-Islam congres (1916), 29-30. Two years later Tjokroaminoto repeated this message "The custom to crouch and present the sembah; maintaining these servile traditions keeps us small, makes us kindhearted; the feeling that we are servants of others persists." Sarekat-Islam congres (1919), 37-38.

43. Adam, The Vernacular Press; Mirjam Maters, Van zachte wenk tot harde hand: persvrijheid en persbreidel in Nederlands-Indië, Igo6-1942 (Hilversum: Uitgeverij Verloren, 1998).

44. Hendrik M. J. Maier, "Phew! Europeesche beschaving! Marco Kartodikromo's Student Hidjo," Southeast Asian Studies 34, no. I (June 1996): 184-210; Ahmat Adam, 
"Radical Journalism and Press Persecution in Java: 1914-I918," JEBAT 20 (1992): 91I05; Shiraishi, An Age in Motion, 8I-87.

45. Pemberita Betawi, no. 234, Oetoesan Hindia, no. 169, 176, and 180, and Kaoem Moeda, no. 287 and 288, $K T_{3}$ (1913): 87-88, 92-94, and 385 .

46. "Siapa jang disediakan?," "Hormat," and "Boenga-rampai dari Zuid Bali," Doenia Bergerak, April 4, 1914, June 13, 1914, and August 29, I914.

47. "Menghormati haroes dengan sepantasnja," Doenia Bergerak, May i6, I9I4.

48. "Hormat circulaire," Doenia Bergerak, May 9, I91 4.

49. "Siapa jang disediakan," Doenia Bergerak, April 4, I9I 4.

50. "Als ik eens regent was ...," Doenia Bergerak, April 25, 1914.

5r. Vreede-De Stuers, The Indonesian Woman, 64-65.

52. Oetoesan Hindia, no. I80, KT, vol. 3 (1913) 92-94. A similar call to action can be found in Kartosiswojo, "Kamerdika'an," Sinar Djawa, April 8, I9I 4.

53. "Keloeh kesah," Doenia Bergerak, 20 June i914.

54. For instance, see the following articles in Doenia Bergerak: "Hormat circulaire I" (July II, I9I4), "Hormat circulaire II” (July II, I9I 4), "Dodok dan sembah?” (July I8, I9I4), "Apakah ini boekan anti circulaire 20I4" (August I, I9I4), "Hormat circulaire tiada di endahkan" (August 8, I9I4), "Pengisap hormat circulaire" (August 20, I9I4), and "B. B. contra pandhuis" (November 7, 1914).

55. “Onze kwaal," Sinar Djawa, April 28, 1914.

56. "Kemadjoean bangsa Djawa," Sinar Djawa, May 28, I914.

57. "Pegawai O. R. ta'dapat kehormatan" and "Masih ada gila hormat," Oetoesan Hindia, June I0, 1914, and June 17, I914.

58. "Hormat circulaire I," Doenia Bergerak, July II, I9I 4. Kartosiswojo, "Kamerdika’an."

59. "Circulaire No. 2014 ," Doenia Bergerak, August 22, 1914.

60. "Circulaire No. 2014," Doenia Bergerak, October 31, I9I 4.

61. Kaoem Moeda, November 25, 1915.

62. Shiraishi, An Age in Motion.

63. "Extract uit het register der besluiten van den Gouverneur-Generaal van Nederlandsch-Indië, 23 september 1913," in Collection Hazeu, H I083, no. 29, UBL; NNI, April 8, 1917, and August 27, 1917; Bataviaasch Nieuwsblad, August 10, 1917; July 27, 1918; August 26, 1919; IG 37, no. 2 (1915): 1631-33; De Taak I, no. 23 and 28 (January 5 and February 9, 1918): 280 and 333.

64. De Wederopbouw 3, no. 2 (1920): 40-48; no. 3 (1920): 5I-54 and 6I-72; no. 4 (1920): 79-90; 4, no. I (1921): 13-20.

65. "De zevende hormat-circulaire en de uitlatingen van Dr. Rinkes," 365-67.

66. M. B. van der Jagt, "Ethische koers en bestuursambtenaar," $K T$ 4, no. 2 (I9I5): II9I-2I5 and $1328-45$.

67. Hazeu to J. P. van Limburg-Stirum, September 29, 1916, and November 30, 1916, in Collection Hazeu, $\mathrm{H}$ 1083, no. 67 and no. 70, UBL.

68. Handelingen van den Volksraad (June 24, I918), 344.

69. Van der Jagt to the Resident of Kedu, March I, I918, in Collection Hazeu, H 1083 , no. 70 , UBL. 
70. J. E. Stokvis, “Het B. B.,” De Taak 2, no. 2 (Augustus Io, 1918, and September 7 , 1918). M. B. van der Jagt, "B. B.," De Taak 2, no. 6 (September 7, 1918): 69-70.

71. Handelingen (November 14, 1918), 159-70.

72. Handelingen (November 14, 1918), 159-70 and $175-85$.

73. Handelingen (November I5, 1918), 190-204.

74. Note by Hazeu titled "Optreden en mentaliteit v/d As.-Resident v.d. Jagt," in Collection Hazeu, $\mathrm{H}_{1083}$, no. 17, UBL.

75. Hazeu to Van Limburg-Stirum, December 9, 1918, Collection Hazeu, H Io83, no. 70 , UBL.

76. Locher-Scholten, Ethiek in fragmenten, 75-84.

77. NNI, April 8,1919, July 25, 1919, and September 23, 1919. Djajadiningrat Hoesein, “Dr. G. A. J. Hazeu," De Taak, no. I2 and 13 (October I8 and 25, 1919).

78. Bintang Timoer, December 8, 1926. Neratja, April 3, 1922, IPO, no. I5 (1922).

79. J. W. Meijer Ranneft, De toekomst van het Binnenlandsch Bestuur, iо.

8०. Van den Doel, De stille macht, 376-87.

81. Neratja, November I8, I9I8, and Kaoem Moeda, November 19, 1918, IPO, no. 47 (1918). Neratja, January 6, 1919, IPO, no. 2 (1919).

82. Kaoem Moeda, January 6, 1919, IPO, no. 2 (1919).

83. Boedi Oetomo, January 25, 1923, IPO, no. 5 (1923); Sinar Hindia, January 22 until 29, 1923, IPO, no. 5 (1923); Hindia Baroe, August 27 until September 2, 1925, IPO, no. 36 (1925); Hindia Baroe, August 27 until September 2, 1925, IPO, no. 36 (1925); Bintang Timoer, December 27, 1926.

84. Ruth McVey, The Rise of Indonesian Communism (Ithaca: Cornell University Press, 1965); Shiraishi, An Age in Motion, 339-42; Van den Doel, De Stille Macht, 38794; Yamamoto, Censorship in Colonial Indonesia, $153-75$.

85. Alexanderson, Subversive Seas, 168-208; Klaas Stutje, Campaigning in Europe for a Free Indonesia: Indonesian Nationalists and the Worldwide Anticolonial Movement, I917-I93I (Copenhagen: NIAS Press, 2019).

86. Handelingen, June 27, 1924, 460.

87. NNI, October 27, 1927.

88. Samuel Kalff, "Eerbewijzen in Indië," Haagsch Maandblad 8 (1927): 651.

89. De Indische Courant, March 28, 1927, and April I4, 1927. NNI, July 6, 1927, August 30, 1927, and November 30, 1930. Soerabaiasch Handelsblad, November 13, 1929.

90. Handelingen (June I2, 1927); Handelingen (July I, 1927), 587.

91. Handelingen (July 15, 1927), 970.

92. Handelingen (July I5, 1927), 966.

93. Handelingen (June 20, 1928), 273.

94. Handelingen (June 15, 1929), 10.

95. Handelingen (August 6, 1929), 609-10.

96. Indische Courant, June 17, 1929. Soerabaijasch Handelsblad, June 19, 1929. Bataviaasch Nieuwsblad, June 19, 1929. Handelingen, July 18, 1928, 127-28.

97. Handelingen (July 26, 1929), 406.

98. Handelingen (July 18, 1929), 166-71. Soerabaiasch Handelsblad, September 4, 1929. 
99. Pertjatoeran, July 6, 1929, and July 25, 1929. Bahagia, July 16, 1929.

100. Handelingen (July I6, 1929), 57-58, 80-82 and 92-93.

гог. Handelingen (July 16, 1929), 137-44, 344-49, 379-82, and 658-63.

102. The circular can be found in Bintang Timoer, April 9, 1929. For further discussion, see Bahagia, May 16 and 17, 1929; Bintang Timoer, April 9, 1929, and September 7, 1929; Onze Bode, May 1929.

I03. The hormat proposal of the Surabaya PPBB can be found in "Minta poenale santie," Soeloeh Ra' jat Indonesia 3, no. 38 (September 18, 1929): 577-78 and Bintang Timoer, September 7, 1929. For further context see "Sebabnja orang ta' soeka djadi prijaji!," Soeloeh Ra'jat Indonesia 3, no. 25 (June 19, 1929): 363-366; Pemimpin, August 1929.

104. The PPBB proposal can be found in Bintang Timoer, August I5, 1930.

105. Handelingen (August 7, 1930), 904; (August 17, 1930), 1081-84.

106. Sipatahoenan, January 20, 1930. Handelingen (August 4, 1932), 990-91; Swara Publiek, June 27, 1931.

107. Soetomo, “'Fahamnja' regent," Soeloeh Ra' jat Indonesia 3, no. 17 (April 24, 1929): 230-3I; Soetomo, "Moeslihatnja regent," Soeloeh Ra' jat Indonesia 3, no. I8 (May I, I929): 246-47; Soetomo, "Sambat pada bawah-perintahnja," Soeloeh Ra' jat Indonesia 3, no. 20 (May 15, 1929): 290-91.

I08. "Sembah dan jongkok," Isteri I, no. 6-7 (October-November 1931); Bintang Timoer, May I8, I93I.

I09. "Hormatstelsel antara goeroe dan pembasar," Persatoean Goeroe, September I5, 1930; Agus Suwignyo, "The Making of Politically Conscious Indonesian Teachers in Public Schools, 1930-42," Southeast Asian Studies 3, no. I (April 2014): 130.

I Io. The issue also reached the floor of the People's Council: Handelingen (August I2, 1931), 796, 86I, 959, and 108I-84.

III. Bintang Timoer, September 28, 1931 .

II2. Aksi, October 8 and 13, 1931. Also see Sedio Tomo, September 16, I931, and October I2, 1931; Bintang Timoer, October 16 and 17, 1931; Persatoean Goeroe, October 5, 1931; Pemimpin, August-September 1931.

II3. Darmo Kondo, October 12, 21, 22, and 27, 1931; Also see Aksi, October I4, I93I.

II 4. Sastrawirja, "Moderne wellevendheid," Djåwå II (193I): 31-38; Hardjosoepoetro, "De oude gebruiken gewijzigd en in harmonie gebracht met de opvattingen van den tegenwoordigen tijd," Djåwå II (1931): 39-49.

II5. The articles were published under the header "Sembah jongkok: Darmo Kondo contra Aksi," Aksi, October 15, 16, 17, and 21, 1931.

116. Aksi, October 17, 1931. For original reports of the incidents see Bahagia, January II, 1929; Sedio Tomo, January 5, 1929.

117. Aksi, October 21, 1931.

II8. For instance, see Soeara Oemoem, March 9, 1933; Sipatahoenan, February 8 and 9 , 1934 . 
I19. Handelingen Volksraad (August 5, 1935), 653; (July 9 and August 2 and 17, I937), I0I, 597, and 988; a similar argument was made by Representative Sorsodiprodjo (September 9, 1937), I333.

I20. Aksi, October 2I, 193I.

\section{Chapter 4. Contesting Sartorial Hierarchies}

I. Raden Moehamad Enoch to Head Inspector Ten Damme, November 24, 1913; Enoch to Hazeu, December I, 1913, in Collection Hazeu, H I083, no. 29, UBL.

2. Ten Damme to Enoch, February 2, I9I 4, in Collection Hazeu, H Io83, no. 29, UBL.

3. See for instance, the rich contributions to the volume edited by Henk Schulte Nordholt, Outward Appearances: Dressing State and Society in Indonesia (Leiden: KITLV Press, 1997), especially Kees van Dijk, "Sarong, Jubbah, and Trousers: Appearance as a Means of Distinction and Discrimination," 39-84; Jean Gelman Taylor, "Costume and Gender in Colonial Java, I800-1940," 85-116; Rudolf Mrázek, "Indonesian Dandy: The Politics of Clothes in the Late Colonial Period, I893-1942," II7-47; Elsbeth Locher-Scholten, "Summer Dresses and Canned Food: European Women and Western Lifestyles in the Indies, 1900-1942," I5I-80. See Jean Gelman Taylor, "Official Photography, Costume and the Indonesian Revolution," in Women Creating Indonesia: The First Fifty Years, ed. Jean Gelman Taylor (Clayton: Monash Asia Institute, 1997), 91-I26; Jean Gelman Taylor, "Identity, Nation and Islam: A Dialogue about Men's and Women's Dress in Indonesia," in The Politics of Dress in Asia and the Americas, ed. Mina Roces and Louise Edwards (Brighton: Sussex Academic Press, 2007), I0I-20; Dorine Bronkhorst and Esther Wils (eds.), Tropenecht.

4. Emma Tarlo, Clothing Matters: Dress and Identity in India (Chicago: University of Chicago Press, 1996), 8-9.

5. Elizabeth Wilson, Adorned in Dreams: Fashion and Modernity (Berkeley: University of California Press, 1987); I-9; Alison Lurie, The Language of Clothes (New York: Random House, 198I), I-3I.

6. Fasseur, "Cornerstone and Stumbling Block," 3I-57. Luttikhuis, "Beyond Race," 539-58.

7. Staatsblad no. IIo and III (1872).

8. Cohn, Colonialism and its Forms of Knowledge, 106-62. Rudolf Mrázek, "The Indonesian Dandy," 1 1 7-20.

9. Staatsblad, no. 22 (1820) and no. 13 (1824).

ı. Taylor, "Costume and Gender," I03-5; Taylor, "Official Photography," 9I-I26; Taylor, "Identity, Nation, and Islam," IоI-7.

II. This distinction between an occidental public sphere and an oriental private sphere can be traced back to the era of the VOC, when European men cohabitated with or married indigenous or Eurasian women, and local culture dominated in domestic spaces. 
V. I. van de Wall, "Indische kleederdrachten," D’Oriënt, October 25, 1924; Taylor, The Social World of Batavia, roo.

I2. Taylor, "Official Photography," ıо3; Veldhuizen, Batik Belanda.

13. Karel Wybrands, "Het naderend einde," NNI, October 5, I916.

I4. Bronkhorst and Wils, Tropenecht, 83; C. Vis-Janssen Van Raay, "De witte kleur bij de Inlandsche volken," De Indische Verlofganger, May II, I928; "De triomf van de witte jas," NNI, August 29, 1905; Alison Lurie, The Language of Clothes, I84-87.

I5. Eric Tagliacozzo, The Longest Journey: Southeast Asians and the Pilgrimage to Mecca (Oxford: Oxford University Press, 2013); Kris Alexanderson, Subversive Seas, 135-67.

16. Advisor for Native Affairs Christiaan Snouck Hurgronje to the Governor General C. P. Hordijk, March 26, 1890, in Ambtelijke adviezen, vol. I, 1318-23.

17. Natalie Mobini-Kesheh, The Hadrami Awakening: Community and Identity in the Netherlands East Indies, 1900-1942 (Ithaca: SEAP, 1999).

18. Suzanne O'Brien, "Splitting Hairs: History and the Politics of Daily Life in Nineteenth-Century Japan," The Journal of Modern Asian Studies 67, no. 4 (2008): 1309-39.

19. Michael R. Godley, "The End of the Queue: Hair as Symbol in Chinese History," East Asian History, no. 8 (1994): 53-72.

20. Tjiook-Liem, De rechtspositie der Chinezen, 250-53.

2r. The term "composite fashion" comes from Emma Tarlo's Clothing Matters, 42-55;

"De evolutie der Javaansche kleeding," De Sumatra Post, April 4, I9I2.

22. Onderzoek naar de Mindere Welvaart, vol. 9a (1907), 53-58.

23. Jean Gelman Taylor, "The Sewing-Machine in Colonial-Era Photographs: A Record from Dutch Indonesia," Modern Asian Studies 46, no. I (2012): 71-95.

24. Snouck Hurgronje to Governor General W. Rooseboom, December 25, 1900, in Ambtelijke adviezen 2, 1326-28.

25. De Sumatra Post, January 12 and October 2, 1900; De Locomotief, June 30, 1902; NNI, October 19, 1903, June 10, 1904, January 20, 1905, and March I, 1905.

26. Snouck Hurgronje to Van Heutsz, June I2, 1905, in Ambtelijke adviezen 2, 1590.

27. Snouck Hurgronje to the Director of Education, Religion, and Industry, October 26, 1902, in Ambtelijke adviezen 2, 1041-45; Hesselink, Healers on the Colonial Market, 169-70; Pols, Nurturing Indonesia, 46-92.

28. Snouck Hurgronje to the Director of Education, October 26, 1902; Bijblad, no. 594I (1904).

29. Preanger Bode, September 19, 1901, November 18, 1901, and April 2, 1902; De Locomotief, December II, 1902; Bataviaasch Nieuwsblad, October 29, 1904, and November 10, 1904; NNI, June 10, 1904; De Sumatra Post, I8 February 1905.

30. Snouck Hurgronje to Van Heutsz, June I2, 1905.

31. Bijblad, no. 624I (1906).

32. Moesa, "Kleeding en adat," Bintang Hindia 3, no. Io (1905): I18-19.

33. Slamet, "Ingezonden," Bintang Hindia 5, no. 4 (1906): 46-47.

34. "Pakaian," Bintang Hindia 4, no. 2 (1906): 18-19; "Adat dan pakaian," Bintang Hindia 5, no. 4 (1907): 4I-42; Pols, Nurturing Indonesia, 25-26. 
35. "Mengapakah orang Jawa tiada membuang rambut panjang?," Bintang Hindia 4, no. 13 (1906): 171; "Apakah gunanya dibuang rambut panjang," Bintang Hindia 5, no. 4 (1907): 40-4I.

36. "Ontwikkeling. .. van kleedij," De Sumatra Post, November 27, 1907.

37. “Teekenen," De Indiër I, no. 29 (May 7, 1914): 46.

38. Arguments about employing dress as a means of curtailing traditional deference had been published since the turn of the century, but it was not until 1913 that the issue received explicit government support in the form of the hormat circular. Bintang Soerabaja, December 29, I9II, KT I (I9II) 96; Van Dijk, "Sarong, Jubbah, and Trousers," 39-84; Mrázek, "Indonesian Dandy," II7-47; Locher-Scholten, "Summer Dresses and Canned Food," I5I-80.

39. Bintang Soerabaja, April 30, 1913, KT 2 (1913), I202; Korver, Sarekat Islam, 52.

40. "Tweede Sarekat-Islam rapport van Dr. Rinkes, dd. 30 November 1915," in Collection Hazeu I083, no. 35, UBL; Korver, Sarekat Islam, 52.

41. Pemberita Betawi, November 30, 1913, KT 3 (1913) 382; "Pakean tjara Europa," Sinar Djawa, February II, 1914; Kaoem Moeda, January 31, I9I4; Soewardi Soerjaningrat, "Javanen in Europeesche kleeding," De Indiër (February 5, 1914), I9I-92; "Inlandsche onderwijzers en de westersche kleederdracht," De Sumatra Post, February 13, 1914.

42. "Pakean tjara Europa," Sinar Djawa, February 26, 1914; Pemberita Betawi, October 30, 1913, KT 3 (1913) 222; "Pengsiap hormat circulaire," Doenia Bergerak, August 29, 1914; "Fourneeren Evolutie pakaian Europa," Sinar Djawa, June 5, I9I4; Tjipto Mangoenkoesoemo, "Het "prestige" in gevaar," De Indiër I (December 4, I913), 82.

43. Soewardi Soerjaningrat, "Europeesche kleeding," De Indiër I, no. Is (January 29, I914): 180.

44. "Lagi lagi hal pakeian," Sinar Djawa, January 20, I9I 4.

45. "Tjerita hal pakaian," Oetoesan Hindia, January I3, I9I 4.

46. Maier, "Phew? Europeesche Beschaving," I84-210; Adam, "Radical Journalism," 9i-I05.

47. "Hormat Circulaire," Doenia Bergerak, May 9, 1914.

48. "Nina boeboek," Doenia Bergerak, March 28, 1914.

49. Pemberita Betawi, September 30, 1913, $K T_{3}$ (1913): 87-88.

50. "Pakaian Europa," Oetoesan Hindia, April I5, I91 4.

51. Kaoem Moeda, May i, i915.

52. Oetoesan Hindia, January 7, 1920.

53. Marco Kartodikromo, "Pakaian Europa," Doenia Bergerak, October 17, 1914.

54. "Chef yang main gila," Doenia Bergerak, May 23, I9I4.

55. "Anti-sepatoe," Doenia Bergerak, May 7, I914.

56. Bunga-rampai dari Zuid-Bali," Doenia Bergerak, August 29, 1914; "Sepakat mendjadi koeat," Doenia Bergerak, April 25, 1914; "Apakah ini boekan anti circulaire no. 2014 ??" Doenia Bergerak, July I8, I9I4; "Berpakaian tjara Europa," Doenia Bergerak, November 28, I9I4. 
57. "Sedikit voorstel tentang pakaian," Oetoesan Hindia, May I6, I9I4.

58. Henk Schutte Nordholt, "The State on the Skin: Clothes, Shoes, and Neatness in (Colonial) Indonesia," Asian Studies Review 21, no. I (1997) 22.

59. Soetatmo Soeriokoesoemo, "Taal en kleeding," De Indiër I, (November I2, I9I4): 9-II.

6o. Farabi Fakih, "Conservative Corporatist: Nationalist Thoughts of Aristocrats: The Ideas of Soetatmo Soeriokoesoemo and Noto Soeroto," BKI I68, no. 4 (2012): 420-44; Hans van Miert, Een koel hoofd en een warm hart: nationalisme, Javanisme en jeugdbeweging in Nederlands-Indië, I9I8-1930 (Amsterdam: De Bataafsche Leeuw, 1995); Takashi Shiraishi, "The Disputes between Tjipto Mangoenkoesoemo and Soetatmo Soeriokoesoemo: Satria vs Pandita," Indonesia 32 (1981): 93-108.

6I. Soewardi Soerjaningrat, "Onze nationale kleeding," De Indiër I, no. 37 (July 2, 1914): 136.

62. Soewardi Soerjaningrat, "Onze nationale kleeding," 138.

63. Hindia Dipa, November 21 and December 5, I921, IPO, no. I (1922). Darmo Kondo, May 24, 1922 and June 3, 1922, IPO, no. 25 (1922).

64. Adas, "Contested Hegemony," 3I-63; Streets-Salter, World War One, 88-iı.

65. Pols, Nurturing Indonesia, 80-91; Van Miert, Een Koel Hoofd.

66. "Prijsvraag," Djawa 3, no. 2 (1923): 92.

67. Bundels met gegevens BG I, No 2; prysvraag kleeding en woning Java Instituut, Special Collections, UBL.

68. The winning essay was significantly edited for publication and can be found in Djawa's archives. Roesalam Dwidjadisastra, "De Europeesche kleederdracht voor Inlanders," Djawa 4, no. 2 (1924): IOI-4; BG I, No 2, UBL.

69. Taylor, "Official Photography," 94-100.

70. Neratja, November 2, 1920, IPO, no. 45 (1920); Oetoesan Melajoe, April 28, 1920, $I P O$, no. 20 (1920); Sinar Hindia, January I2, 1921, IPO, no. 3 (1921).

71. Taylor, "Official Photography," 94-100; Vreede-De Stuers, The Indonesian Woman.

72. Taylor, "Costume and Gender," I09; Luttikhuis, "Negotiating Modernity," I7I206; Kenji Tsuchiya, "The Taman Siswa Movement-Its Early Eight Years and Javanese Background," Journal of Southeast Asian Studies 6, no. 2 (1975): 164-77.

73. Groeneboer, Gateway to the West, 497-98.

74. "Teekenen," 46.

75. Panggoegah, August I, I921, IPO, no. 22 (1921).

76. Soeriokoesoemo, "Taal en kleeding," 9-II.

77. Panggoegah, September Io and 20, 1921, IPO, no. 39 (1921).

78. Dwidjadisastra, "De Europeesche kleederdracht voor Inlanders," I04.

79. Taylor, "Official Photography," 91-126.

80. Kaoem Moeda, February 6, I922, IPO, no. 7 (1922); Pertjatoeran, June 23 and 27, 1925, IPO, no. 29 (1925); Pantjadjania, May 21, 1926, IPO, no. 24 (1926); Sedijo Tomo, September 21 and 26, 1927, IPO, no. 40 (1927).

81. Djawa Tengah, January 5, 1920, IPO, no. 6 (1920). 
82. Sri Djojobojo, April 28, 1924, IPO, no. 23 (1924).

83. Sinar Hindia, November 30, 1918, IPO, no. 48 (1918); Kaoem Moeda, May 10, 1919, IPO, no. I9 (1919).

84. Mrázek, "Indonesian Dandy," I2 I.

85. Ann Laura Stoler, "Sexual Affronts and Racial Frontiers: European Identities and the Cultural Politics of Exclusion in Colonial Southeast Asia," Comparative Studies in Society and History 34, no. 3 (1992): 514-51.

86. Tarlo, Clothing Matters, 33-42.

87. Wybrands, "Het naderend einde."

88. Patricia Spyer, "The Tooth of Time, or Taking a Look at the 'Look' of Clothing in Late Nineteenth-Century Aru," in Border Fetishisms: Material Objects in Unstable Spaces, ed. Patricia Spyer (New York: Routledge, 1998), I50-82; Mrázek, "Indonesian Dandy," I32; "Inlanders in Europ. kleederdracht," NNI, June 25, I919.

89. Handelingen (November 15, 1918), 200-201.

90. Van der Jagt, "Ethische koers en bestuursambtenaar," I203-4.

9I. "Vooruitgang," NNI, June I 4, 1916.

92. Locher-Scholten, "Summer Dresses and Canned Food," I58-6r; Taylor, "Costume and Gender," IоI-5; Bronkhorst and Wils, Tropenecht, 28-43; Vilan van de Loo, "Tobben in Indië: wijze vriendinnen adviseren Hollandse vrouwen," Indische Letteren 9, no. 2 (July 1994): 66-80.

93. Bas Veth, Het leven in Nederlandsch-Indië (The Hague: P. N. Van Kampen \& Zoon, 1900), 25-27.

94. Koopman, Het paradijs der vrouwen: tegenschrift op Veth's "Leven in Indië" (The Hague: N. Veenstra, 1900), I6-17.

95. J. M. J. Catenius-van der Meijden, Ons huis in Indië: handboek bij de keuze, de inrichting, de bewoning en de verzorging van het buis met bijgebouwen en erf, naar de eischen der hygiene, benevens raadgevingen en wenken op huishoudelijk gebied (Semarang: Masman \& Stronk, 1908).

96. Maurits Wagenvoort, Nederlandsch-Indische menschen en dingen (Amsterdam: H. J. W. Becht, 1910).

97. Henri Borel, "Wat in Indië verdwijnt," Het Vaderland, October 19, 1920.

98. Borel, "Wat in Indië verdwijnt."

99. Van de Wall, "Indische kleederdrachten”; D. C. M. Bauduin, Het Indische leven (The Hague: H. P. Leopold, 1927), 12-18; Jo van Ammers-Kuller, Wat ik zag in Indië (Amsterdam: J. M. Meulenhof, 1939), 87.

I00. Locher-Scholten, "Summer Dresses and Canned Food," I60; Taylor, "Costume and Gender," I05-8; Bronkhorst and Wils, Tropenecht, x, 28-43; Veldhuisen, Batik Belanda, $128-29$.

I0I. "Lain doeloe! Lain sekarang!," De Reflector, July I4, 1917.

I02. "Het hooglied van de sarong kabaai," De Reflector, November 9, 1918. For other examples: "De sarong," Het Indische Leven, May 28, 192 I, 810-1I. "Uit mijn Boudoir: De sarong-kabaja," De Zweep, February 4, 1922. 
I03. Locher-Scholten, "Summer Dresses and Canned Food," I6I-75; "Winkelbezoek," De Reflector, January 8, 1916. "Modern Bandoeng," Het Indische Leven, October II, I919, I5I; "Een bezoek aan au Palais des Modes," Het Indische Leven, December 6, 1919, 308; "De installatie van het nieuwe warenhuis 'Adler," D'Oriënt, October I5, 1927.

I04. D’Oriënt, February I3, 1926.

I05. Barlow, Tani E., Uta G. Poiger, Priti Ramamurthy, Lynn M. Thomas, and Alys Eve Weinbaum, "The Modern Girl around the World: A Research Agenda and Preliminary Findings," Gender \& History 17, no. 2 (2005): 245-94.

106. D'Oriënt, August 24, 1929; September 28, 1929; April 19, 1930.

I07. B. van Helsdingen-Schroevers, De Europeesche vrouw in Indië (Baarn: HollandiaDrukkeriy, 1914) 22-45.

108. Gouda, Dutch Culture Overseas; Taylor, The Social World of Batavia; Stoler,

"Making Empire Respectable," 634-60.

I09. "Vrouwen met kort haar," D’Oriënt, March I2, 1927.

I Io. “Haar 'A la ninon' en het moderne jonge meisje," D’Oriënt, May 24, 1924.

III. "De Mode: Sportweek," De Reflector, April 21, 1917.

II2. "Het 'moderne' meisje," De Zweep, January 21, 1922. "Kort of lang haar: is kort haar blijvend?," D’Oriënt, January I5, 1927. “Rookende vrouwen”, D’Oriënt, March 19, 1927.

II3. Barlow, "The Modern Girl around the World," 245-94.

II 4. "Kleeding-Excessen," De Indische Courant, October 8, 1927.

II5. "Batavia bij avond en nacht: dwars door Chinatown," De Revue, July 2, 1921; "Film en werkelijkheid: het prestige der vrouw," De Indische Courant, October 31, 1925.

I16. "Bioscoop-gevaar," NNI, May I, I919.

II7. "Het westersche prestige," NNI, February 25, 1929; "Westersch prestige en de bioscoop," De Sumatra Post, August 9, 1932; Locher-Scholten, "Summer Dresses and Canned Food," 165-75; Bronkhorst and Wils, Tropenecht, I12-4I.

II8. Pols, Nurturing Indonesia, 82-92; Van Miert, Een koel hoofd en een warm hart.

I19. The Indonesian National Association (Perserikatan Nasional Indonesia) was renamed the Indonesian National Party (Partai Nasional Indonesia) in 1928. The acronym, PNI, remained the same.

120. Anderson, Imagined Communities.

I2I. Elson, The Idea of Indonesia, 64-72.

122. Darmo Kondo, August 14, 1930, IPO, no. 34 (1930).

I23. "A-la Indonesia, bagaimana?, Bintang Timoer, August 16, 1930.

I24. "Nasionalisme. . dioejoeng "petji"!," Bintang Timoer, August 23, 1930.

I25. Wilson, Adorned in Dreams, I4; Schutte Nordholt, "The State on the Skin," 22-23; Mrázek, "Indonesian Dandy," 137-39.

I26. "Pakaian nasional," Bintang Timoer, May 8, 9, II, I2, I3, and I5, 1931.

I27. Darmo Kondo, October I4, 1930, IPO, no. 43 (1930).

128. Achmad Sukarno and Cindy Adams, Sukarno: An Autobiography as Told to Cindy Adams (New York: Bobbs-Merill, 1965): 5 I.

I29. KITLV Digital Image Library, Image Code 3725, UBL.

I30. "Pakaian nasional I," Bintang Timoer, May 8, I93I. 
I3I. "Nasionalisme ... dioejoeng "petji"!," Bintang Timoer, Augustus 23, 1930.

132. For a good selection of clothing advertisements: Oetoesan Hindia, December 6, 1920; Kemadjoean Hindia, April 28, 1923; Bahagia, June 4, 1929; Aksi, June 29, 193 I.

133. "Pakaian pantalon," Bahagia, June 3, 1929.

134. Bintang Timoer, September 17, 1931.

135. Bintang Timoer, January II, 1929.

136. "Pakaian nasional I," Bintang Timoer, May 8, 193 I.

137. Bahagia, November 26, 1931, and March 21, 1933.

138. Radio, July 27, 1929, IPO, no. 32 (1929).

139. "Koerang 'aibkah?," Pembela Islam, no. 23 (April I93I): $2-4$.

I 40. Sedio Tomo, August 24 and 25, 1931, IPO, no. 36 (1931).

I4I. Djanget, December 21, 1928, IPO, no. I (1929).

I42. "Pakaian kebesaran asli," Soera 'Aisjijah 3, no. 8-I2 (January-May 1929): 7.

I43. Vreede-De Stuers, 89-99; Martyn, The Women's Movement, 30-51.

I 44. "Pakaian nasional," Bintang Timoer, May 8, 9, II, I2, I3, and I5, I93I; "Mode," Isteri I, no. 6-7 (October-November 1931).

I45. Sukarno and Adams, Sukarno, 80-8I; Taylor, "Official Photography," II9-I2O.

\section{Chapter 5. East Is East and West Is West}

I. "Student Hidjo" appeared as a serial in Sinar Hindia in 1918. It was published as a novel the following year. Marco Kartodikromo, Student Hidjo (Semarang: Masman en Stroink, 1919).

2. Interestingly, the rest of the poem contradicts the meaning of Kipling's infamous first line, emphasizing that people from different backgrounds can be equals.

3. D'Oriënt, September 6, 1924.

4. Indonesia Raja, April 3, 1929, IPO, no. Is (1929).

5. Sin Po, March 2, I931, IPO, no. 13 (1931).

6. Annemarie De Knecht-van Eekelen, "The Debate about Acclimatization in the Dutch East Indies (1840-1860)," Medical History, no. 20 (2000): 70-85; Pols, "Notes from Batavia," I20-48.

7. Pols, "Notes from Batavia," I2 I-22 and $135-38$.

8. Cornelis Swaving, "Iets over den invloed van het klimaat dezer gewesten op den Europeaan," Natuur-en Geneeskundig Archief voor Neerlands-Indië I (1844): 86-87; Cornelis Swaving, "De invloed van Java's klimaat op den gezonden Europeaan en gezondheidsregelen voor den nieuw uitgekomene," Indisch Archief I (1849): 16I-80.

9. For an overview on acclimatization and scientists in colonial Indonesia, see Goss, The Floracrats, 36-59.

I0. Carl Waitz, Onderrigtingen en voorschriften, om de gewone ziekten van Europeanen in heete gewesten te ontgaan, en zich aldaar spoedig aan het klimaat te gewennen, bijzonder met betrekking tot Nederlandsch Indië (Amsterdam: Sulpke, I829); Pols, "Notes from Batavia," I28-3I. 
II. For more pessimistic perspectives on the issue of acclimatization see Franz Junghuhn, "De gematigde en koude streken van Java, met de aldaar voorkomende warme bronnen: uit een natuur-aardrijks-en geneeskundig oogpunt beschouwd, als stellende een middel daar ter voorkoming en genezing van die ziekten, waaraan Europeanen, ten gevolge van hun lang verblijf in heete luchtstreken, gewoonlijk lijden," TNI 4, no. 2 (I842): $8 \mathrm{I}-82$.

I2. This is in contrast to British, French, and American colonies, where fears of racial degeneration came to dominate the debate on acclimatization much earlier, see Dane Kennedy, "The Perils of the Midday Sun: Climatic Anxieties in the Colonial Tropics," in Imperialism and the Natural World, ed. John Mackenzie (Manchester: Manchester University Press, 1990) II8-40; Eric T. Jennings, Curing the Colonizers: Hydrotherapy, Climatology, and French Colonial Spas (Durham and London: Duke University Press, 2006); Warwick Anderson, Colonial Pathologies: American Tropical Medicine, Race, and Hygiene in the Philippines (Durham: Duke University Press, 2006).

I3. L. H. Verwey, De acclimatatie van Nederlanders in Indie, en van Indiërs in Nederland (The Hague: P. J. Kraft, 1863); C. L. van der Burg, Persoonlijke gezondheidsleer voor Europeanen die naar Nederlandsch-Indië gaan of daar wonen (Amsterdam: J. H. de Bussy, i895).

I4. Christiaan Eijkman, "Vergelijkend onderzoek van de physische warmteregeling bij den Europeeschen en den Maleischen tropenbewoner," Geneeskundig Tijdschrift voor Nederlandsch-Indië 34 (1894): 544-80.

I5. Eijkman, Over gezondheid en ziekte, 20.

I6. J. H. F. Kohlbrugge, “Climatologie en tropische ziekten," TNI 4 (1900): 119-24; J. H. F. Kohlbrugge, Blikken in het zieleleven van den Javaan en zijner overheerschers (Leiden: Brill, 1907) 47-52 and 90-10I.

17. Michael Adas, Machines as the Measure of Men: Science, Technology, and Ideologies of Western Dominance (Ithaca: Cornell University Press, 1989), 307-16.

I8. Gouda, Dutch Culture Overseas, II8-56; Sysling, Racial Science, I-24.

19. Kohlbrugge, Blikken in het zieleleven, III-I2.

20. Kohlbrugge preferred the term "metamorphoses" over degeneration, but from his argumentation it is clear that he meant degeneration. This was not lost on his contemporaries. Kohlbrugge, Blikken in het zieleleven, 109-14 and 128 . See the criticism of Christiaan Snouck Hurgronje, "Blikken in het zielenleven der Javaan?," De Gids 72 (1908): 423-47.

21. Kohlbrugge, Blikken in het zieleleven, 90.

22. Carlo [pseud.], "Indische indrukken," WVI, March II, I906. Also see R. Broersma, "Java's Kolonisatie en de Wetenschap," WVI, January 24, 1909.

23. Onderzoek naar de Mindere Welvaart, vol. XII, 6-22.

24. Kohlbrugge, Blikken in het zieleleven, I28; J. H. F. Kohlbrugge, "The Influence of a Tropical Climate on Europeans," The Eugenics Review 3, no. I (I9II): 25-36.

25. This popular proverb derived from Goethe's Wablverwandschaften (1809): "Es wandelt niemand ungestraft unter Palmen." For instance, see Corax [pseud.], "Indrukken van den dag XXIV," WVI, July 28, 1907. 
26. Anna Crozier, "What Was Tropical about Tropical Neurasthenia? The Utility of the Diagnosis in the Management of British East Africa." Journal of the History of Medicine and Allied Sciences 64, no. 4 (2009): 518-48.

27. Anna Greenwood, "The Strange History of Tropical Neurasthenia," The Psychologist 24, no. 3 (2011): 226-27.

28. F. H. G. van Loon, "Het zenuwlijden der blanken in de tropen," Geneeskundig Tijdschrift voor Nederlandsch-Indië 67 (1927): 435-78; F. H. G. van Loon, "Wie is geschikt voor de tropen?, KT i9 (1930): I-25.

29. "Sanatogen: A Scientific Investigation of Its Alleged Action on the Recuperating Powers of the Blood," Journal of the American Medical Association 63, no. 13, (I914): 1127-29.

30. Sanatogen's impressive advertising campaign lasted roughly from 1910 to 1930 . For a very small selection of its diverse advertisements, see NNI, June 9 and November 5 , I910; January 5, I911; July s and September 26, 1912; April 28, 1913; April 2, 1928.

31. De Indische Courant, June 16, 1926.

32. Van der Burg, Persoonlijke zezondheidsleer, I53; A. H. Nijland, Hygiënische wenken voor het leven in Nederlandsch-Indië (Leiden: S. C. van Doesburgh, 1921), 35; E. H. Hermans, Gezondheidsleer voor Nederlandsch-Indië: een boek voor ieder die naar Indië gaat, of daar woont (Amsterdam: J. M. Meulenhoff, 1925), 33-43.

33. G. J. Nieuwenhuis, Lichamelijk opvoeding in Indië (Weltevreden: Vereeniging Nederlandsch-Indisch Onderwijs Kongres, I918); "Sport en succes in het leven," De Reflector, December 25, 1915; "Iets over lichamelijke opvoeding," Het Indische Leven, December 2, 1922; "Sport in Netherland India," Tourism in Netherland India 7, no. 6 (1932).

34. Jennings, Curing the Colonizers, I-7.

35. Anderson, Colonial Pathologies, I-I2.

36. Locher-Scholten, "So Close and Yet So Far," I3I-53.

37. Gouda, "Nyonyas on the Colonial Divide," 318-42.

38. "Het Kind en de Baboe," WVI, October 5, I919, 366.

39. Ofoei [pseud.], "Indische Penkrassen XXI," WVI, February 5, I9II; "Het Baboeisme en de Pest," Bijblad van het WVI voor Dames, June II, I9II; "Het Kind en de Baboe," WVI, October 5, I919.

40. Frances Gouda, "Good Mothers, Medeas, or Jezebels: Feminine Imagery in Colonial and Anticolonial Rhetoric in the Dutch East Indies, 1900-1942," in Domesticating the Empire, 236-54.

4I. Ofoei [pseud.], "Indische penkrassen XXI," $W V I$ 7, no. 42 (I9II): 701 -2.

42. Van Helsdingen-Schoevers, De Europeesche vrouw in Indië, 25-26.

43. Ofoei [pseud.], "Indische Penkrassen XXIX," WVI 8, no. 6 (I9II): I26-28.

44. The Quaker Oats advertisement campaign in the colonial press was modern, intelligent, and appealing. For instance, see the numerous advertisements in the weekly D'Oriënt 4, no. 36 and 49 (1925); 5, no. I0, 40, 44, and 48 (1926); 6, no. 4, 5, II, I3, I4, and I6 (1927); 8, no. I, 3, 4 (1928); I7, no. I 4 (1938).

45. Locher-Scholten, "Summer Dresses and Canned Food," I5I-80. 
46. M. Buijsman, "Tarwe in Indië," Algemeen Landbouwweekblad voor Nederlandsch-Indië 2, no. 6 (1917).

47. On the difficulty of disentangling identities in India, see Ashis Nandy, The Intimate Enemy: Loss and Recovery of Self under Colonialism (New Delhi: Oxford University Press, 1988).

48. Schulte Nordholt, "Modernity and Cultural Citizenship," 435-57; Hoogervorst and Schulte Nordholt, "Urban Middle Classes in Colonial Java," 442-74.

49. Laffan, Islamic Nationhood, 47-76 and 165-69; Kartodirdjo, Pengantar sejarah Indonesia baru 2, $106-1$; Korver, Sarekat Islam, 5-13; M. C. Ricklefs, Polarizing Javanese Society: Islamic and Other Visions, c. 1830-1930 (Honolulu: University of Hawaii Press, 2007), 214-50; Noer, The Modernist Muslim Movement, I-29; Formichi, Islam and the Making of the Nation, I-I 4.

50. Sinar Hindia, November 30, 1918, IPO, no. 48 (1918); Neratja, December 13, 1920 and May 28, 1921; Adas, "Contested Hegemony," 49-55.

51. Hindia Dipa, September 5, I921.

52. Ki Hadjar Dewantara, "Some Aspects of National Education and the Taman Siswa Institute of Jogjakarta," Indonesia 4 (1967): 152.

53. "De Theosophie en Boedi-Oetomo," IG 31, no. I (1909): 534-35; “Toestanden in de Vorstenlanden," IG 34, no. I (1912): 797-800.

54. S. S. J. Ratu Langie, Serikat Islam (Baarn: Hollandia, 1913), 20.

55. Korver, Sarekat Islam: 49-78.

56. J. F. H. A. Later, “De Inlandsche beweging," $I G$ 38, no. 2 (I916): 922.

57. Sinar Djawa, no. 172, $K T_{3}$ (1913): 1398.

58. Jiří Jákl, "An Unholy Brew: Alcohol in Pre-Islamic Java," The Newsletter, no. 77 (2017).

59. Ricklefs, Polarizing Javanese society, 254; Pemberton, On the Subject of "Java", 68-ior.

60. Bintang Soerabaja, May 31, 1912, KT I (1912): 833-34; A. H. J. G. Walbeehm, "Een drankverbod voor Nederlandsch-Indie," Indisch Genootschap (January I6, 1912): I19-47.

61. Oetoesan Hindia, July 2, 1915, KT 4 (1915): 1393; Pemberita Betawi, October 1, 1916, KT 5 (1916): 213 .

62. Ardjoena [pseud.], "Ook dat nog," De Indiër 1, no. 6 (1913): 65-66.

63. Bintang Soerabaja, no. 154, KT 2 (1913): 1485-86.

64. Hazeu to Van Heutsz, 30 December 1908, in Collection Hazeu, H Io83, no. 24, UBL; Tjipto Mangoenkoesoemo, "De Indische Regeering moet zich schamen," De Indiër I, no. II (1914): 130; Rush, Opium to Java; Siddhartha Chandra, "What the Numbers Really Tell Us about the Decline of the Opium Regie," Indonesia 70 (2000): $101-23$.

65. Tjipto Mangoenkoesoemo, "Het Binnenlandsch Bestuur," De Indiër 2, no. 154 (1918).

66. "Wat het Oosten van het Westen noodig heeft," De Indiër I, no. I8 (1914): $205-6$.

67. "Hal dansah," Isteri i, no. 4 (August 1929).

68. "Lagi hal dansah," Isteri I, no. 6 (October 1929). 
69. Oetoesan Hindia, January I3, I921, IPO, no. 3 (1921); Kaoem Moeda, February II, I922; Vreede-de Stuers, The Indonesian Woman; Martyn, The Woman's Movement in Post-Colonial Indonesia, 30-51.

70. Ricklefs, Polarizing Javanese Society, 251-57.

71. Stoler, Carnal Knowledge, I-139; Gouda, "Nyonyas on the Colonial Divide," 318-42; Locher-Scholten, Women and the Colonial State, 187-218; Hanneke Ming, "Barracks-Concubinage in the Indies, 1887-1920," Indonesia 35 (1983): 65-93; Betty de Hart, “'De verwerpelijkste van alle gemengde huwelijken': De gemengde huwelijken regeling Nederlands-Indie I 898 en de rijkswet op het Nederlanderschap I892 vergeleken," Gaan \& staan. Jaarboek voor de vrouwengeschiedenis 2I (Amsterdam: Stichting Beheer IISG, 200I): 60-8I.

72. Taylor, The Social World of Batavia, 14-16.

73. Van Marle, "De groep der Europeanen," 97-I2I, 314-4I, and 48I-507; Reggie Baay, De njai: het concubinaat in Nederlands-Indië (Amsterdam: Athenaeum-Polak \& Van Gennep, 2008).

74. Taylor, The Social World of Batavia, 15-17; Stoler, "Making Empire Respectable," 634-60.

75. Eckart, Indische brieven; Adelante [pseud.], "Concubinaat bij de ambtenaren van het binnenlandsch bestuur in Nederlandsch-Indië," TNI 2 (1898): 304-I4 and 6I0-17; J. H. F. Kohlbrugge, "Prostitutie in Nederlandsch Indie," Indisch Genootschap (February 19, 190I): 17-36; R. A. Kern, “De kontroleurs en 't concubinaat," TBB 28 (1905): 250-52.

76. Ming, "Barracks-Concubinage," 65-93. Stoler, Carnal Knowledge.

77. Wagenvoort, Nederlandsch-Indiche menschen en dingen, 90-95; Van HelsdingenSchoevers, De Europeesche vrouw in Indië, 6-8.

78. Van Marle, "De groep der Europeanen," 322-23.

79. Van Marle, "De groep der Europeanen," 314-4I.

80. J. A. Nederburgh, Gemengde huwelijken: Staatsblad I898 no. I5: officieele bescheiden met eenige aanteekeningen (Batavia, I899), 9-21; Betty de Hart, "'De verwerpelijkste van alle gemengde huwelijken," 60-8I.

8I. Van Marle, "De groep der Europeanen," 491; Pantjaran Warta, no. 258, 259, and 265, KT 3 (1913): 225; “Als de Sarekat Islam naar Deli komt," De Telegraaf, July i, I913.

82. Korver, Sarekat Islam, 49-78.

83. Pedro [pseudonym], "Sikapnya bangsa Europa terhadap pada perempoean Boemipoetera," Kemadjoean Hindia, June 5, 1923; Sally White, "The Case of Nyi Anah: Concubinage, Marriage and Reformist Islam in Late Colonial Dutch East Indies," Review of Indonesian and Malaysian Affairs 38, no. I (2004): 87-98.

84. Kawan Kita Jang Toeloes, February 7, 1919, IPO, no. 7 (1919); Poesaka, June 2, 1919, IPO, no. 23 (1919); Djawi Hisworo, November 19, 1919, IPO, no. 48 (1919).

85. Ki Wiroloekito, "Gemengde huwelijken," De Vrouw in Indië, May I, I9I5.

86. "Een niet alledaagsche verloving," Algemeen Handelsblad, June 8, i915.

87. Sinar Djawa, no. 134, KT 4 (1915): 1238-39.

88. "Een opzienbarende verloving," Bataviaasch Nieuwsblad, April 27, 1915. 
89. For more examples, see Kaoem Moeda, no. 228, KT 5 (1916): 86; Neratja, September 7-9, 1920, IPO, no. 37 (1920); Oetoesan Hindia, September 8, 1920, IPO, no. 37 (1920); Oetoesan Hindia, November 22, 1920, IPO, no. 48 (1920); Oetoesan Hindia, December I2 until 19, I922, IPO, no. 51 (1922); De Sumatra Post, November 13, I915; "Gemengde huwelijken," IG 38, no. 2 (1916): 979-80.

90. "Kawin dengan lain bangsa (gemengd huwelijk)," Perempoean Bergerak, December 16, 1919.

91. "Doenia Istri," Padjadjaran, October 25, 1920.

92. Vreede-de Stuers, The Indonesian Woman, 61-74; Pemberita Betawi, no. 283, KT 2 (1912): 595; Poesaka, June 2, 1919, IPO, no. 23 (1919).

93. Oetoesan Hindia, November 22, 1920, IPO, no. 48 (1920); Boedi Oetomo, December 3, 1920, IPO, no. 49 (1920).

94. Sinar Pasoendan, March 22, 1919, IPO, no. I2 (1919). A similar advertisement can be found in Darmo Kondo, March I5, I928, IPO, no. I2 (1928).

95. Part of the study committee's letter as well as Sam Ratu Langie's response can be found in "Bespreking over gemengde huwelijken in de vergadering der Indische Vereeniging op 30 Juni 1915," Indische Vereeniging: Voordrachten en Mededeelingen, no. Io (1916): 56-59.

96. "Bespreking over gemengde huwelijken," 59-73.

97. Examples of Indonesian men with a European spouse are discussed in Van Marle, "De groep der Europeanen," 336.

98. Boedi Oetomo, December 3, 1920, IPO, no. 49 (1920); Warta Hindia, December 18, 1924, IPO, no. I (1925).

99. Oetoesan Hindia, January 8, 1919, IPO, no. 2 (1919); Kawan Kita Jang Toeloes, February 7, 1919, IPO, no. 7 (1919); Neratja, June 16, 1919, IPO, no. 25 (1919).

Ioo. Kartodikromo, Student Hidjo.

ıог. Abdoel Moeis, Salah Asoehan (Weltevreden: Balai Poestaka, 1928); Keith Foulcher, "Biography, History and the Indonesian Novel: Reading Salah Asuhan," BKI I6I, no. 2/3 (2005): 247-68.

I02. Habib St. Maharadja, Nasib (Batavia: Balai Poestaka, 1932); A. L. V. L. van der Linden, De Europeaan in de Maleische literatuur (Meppel: B. ten Brink, 1937): 433-52. I03. John Ingleson, "Sutomo, the Indonesian Study Club and Organised Labour in Late Colonial Surabaya," JSEAS 39, no. I (2008): 31-57.

I04. Paul W. van der Veur, Towards a Glorious Indonesia: Reminiscences and Observations of Dr. Soetomo (Athens: Ohio University Center for Southeast Asian Studies, 1987), 91; Neratja, January 7, 1919, IPO, no. 2 (1919).

I05. Bintang Mataram, December 20, 1930, IPO, no. 2 (1913); Swara Publiek, December 27, 1930, IPO, no. 2 (1931); Oetoesan Sumatra, January 30, 1931, IPO, no. 7 (193I); Bintang Mataram, January 30, I931, IPO, no. 7 (193I); Darmokondo, February I4, 1931, IPO, no. 8 (1931).

106. Oetoesan Soematra, January 22, 1931, IPO, no. 5 (1931).

I07. Soeara Indonesia, January 5-15, I931, IPO, no. 4 (1931). 
108. Darmokondo, January 24, I931, IPO, no. 4 (1931); Nan Sing, January 16, I931, IPO, no. 4 (1931).

I09. Paul W. van der Veur, Towards a Glorious Indonesia, 99.

\section{Chapter 6. Staging Colonial Modernity}

I. "Naar de Soerabajasche jaarmarkt-tentoonstelling," WVI, June I6, I907.

2. Coté, "Staging Modernity," I-44.

3. M. I. Cohen, Inventing the Performing Arts: Modernity and Tradition in Colonial Indonesia (Honolulu: University of Hawai'i Press, 2016), 83-Ior.

4. Nurliani Lukito, Exhibiting Modernity, 17-68.

5. Joost Coté, “'To See is to Know': The Pedagogy of the Colonial Exhibition, Semarang, I914," Paedagogica Historica 36, no. I (2000): 340-66; Coté, "Staging Modernity," I-44.

6. For the world's fairs, see Marieke Bloembergen, Colonial Spectacles: The Netherlands and the Dutch East Indies at the World Exhibitions, 1880-193I (Singapore: Singapore University Press, 2006); P. A. Morton, Hybrid Modernities: Architecture and Representation at the 193I Colonial Exposition, Paris (Cambridge: MIT Press, 2003); R. W. Rydell, All the World's a Fair: Visions of Empire at American International Expositions, 1876-19I6 (Chicago: University of Chicago Press, 1987).

7. Locher-Scholten, Ethiek in fragmenten, 176-208; Van Doorn, De laatste eeuw van Indië; Houben, "Representations of Modernity," 23-40.

8. Schulte Northolt, "New Urban Middle Classes in Colonial Java," 439-41; Schulte Northolt and Hoogevorst, "New Urban Middle Classes in Colonial Java," 442-74; Dafna Ruppin, "The Emergence of a Modern Audience for Cinema in Colonial Java," BKI, Vol. 173, no. 4 (2017) 475-502.

9. Van Niel, The Emergence of the Modern Indonesian Elite; Schulte Nordholt, "Modernity and Cultural Citizenship," 435-57; Takashi Shiraishi, An Age in Motion, 27-40.

Io. Houben, "Representations of Modernity," 25.

II. For non-Indonesian examples: George Dutton, "Advertising, Modernity, and Consumer Culture in Colonial Vietnam," in The Reinvention of Distinction: Modernity and the Middle Class in Urban Vietnam, ed. V. Nguyen-Marshall, L. B. W. Drummond, and D. Bélanger (New York: Springer, 20I2), 2I-42; Mark Liechty, Suitably Modern: Making Middle-Class Culture in a New Consumer Society (Princeton: Princeton University Press, 2003), I-7; Sanjay Joshi, Fractured Modernity: Making of a Middle Class in Colonial North India (New Delhi: Oxford University Press, 2001), I-22.

I2. J. H. Abendanon, Rapport van den directeur van onderwijs, eeredienst en nijverheid betreffende de maatregelen in het belang van de Inlandsche nijverheid op Java en Madoera in verband met de door het moederland voor dit doel beschikbaar te stellen fondsen (Batavia: Landsdrukkerij, 1904) vol. I, 48-50 and vol. 2, 247-55. 
I3. Onderzoek naar de Mindere Welvaart, vol. 6a, I2-I4 and I46-48; vol. 9, 56-57. I4. Abendanon, Rapport, I2-13, 217.

I5. C. M. Pleyte, Verslag nopens de Pasar-Gambir: Gehouden op het Koningsplein te Weltevreden van I8 Augustus-2 September 1906 (Batavia: Landsdrukkerij, 1907), 10.

I6. J. E. Jasper, Verslag van de eerste tentoonstelling-jaarmarkt te Soerabaja. (Batavia: Landsdrukkerij, 1906).

17. Susie Protschky, Photographic Subjects: Monarchy and Visual Culture in Colonial Indonesia (Manchester: Manchester University Press, 2019); Bloembergen, Colonial Spectacles, 246-55; Cohen, Inventing the Performing Arts, 84-86; V. I. van de Wall, "Pasar Gambir voor Honderd Jaren," D’Oriënt 3, no. 35 (1924).

18. M. A. J. Kelling, "Het jaarbeurswezen in Nederlandsch-Indië," Koloniale Studiën 9, no. 2 (1925): 212-15; "34 jaren bij het Binnenlandsch Bestuur," Soerabaiasch Handelsblad, June 8, 1929.

19. J. E. Jasper, Verslag van de vierde tentoonstelling-jaarmarkt te Soerabaja (Batavia: Landsdrukkerij, 1909); Pleyte, Verslag nopens de Pasar-Gambir; "De jaarmarkt," Bataviaasch Nieuwsblad, August 27, 1906; "De Pasar Gambir," NNI, August 26, 1907.

20. Bloembergen, Colonial Spectacles, 223-25.

21. Abendanon, Rapport, vol. I, I4, and 23; Onderzoek naar de Mindere Welvaart, vol. 9 a, $53-58$.

22. Jasper, Verslag van de vierde tentoonstelling-jaarmarkt.

23. Kelling, "Het jaarbeurswezen in Nederlandsch-Indië," 210-I2; Van Dijk, The Netherlands Indies and the Great War.

24. G. J. Dijkerman, "Het jaarmarktwezen in Nederlandsch-Indië," Koloniale Studiën II, no. 2 (1927): I2I-52; Kelling, "Het jaarbeurswezen in Nederlandsch-Indië," 210-42.

25. Jaarverslag Nederlandsch-Indische jaarbeurs te Bandoeng (Tegal: De Boer, 1929-1933); S. A. Reitsma, "Bandoeng en de jaarbeurs," D’Oriënt 6, no. 26 (1927); “Openingsrede Ten Damme, 17-9-1922," De Jaarbeurs, January 15, 1922.

26. "De jaarmarkt," Indische Courant, July 28, 1923; Programma van de Soerabaiasche jaarmarkt Vereeniging (Surabaya, 1924-1931).

27. Kelling, "Het jaarbeurswezen in Nederlandsch-Indië," 226-39; "Jaarbeurs en jaarmarkt," Indische Courant, June 29, 1923; "De verhouding tusschen de Nederl. Ind. Jaarbeurs-Vereeniging te Bandoeng en de Jaarmarkt-Vereeniging te Soerabaia," De Jaarbeurs, April I5, 1923.

28. "Bevordering van het jaarmarktwezen in Indië," Indische Courant, March 29, 1928. 29. Lukito, Exhibiting Modernity, 17-68; Susie Protschky, Photographic Subjects, 87.

30. "Dertig jaar in Indië in drie minuten," Bataviaasch Nieuwsblad, June II, 1937.

31. A. E. Simon Thomas, De importeur, de pasar gambir, jaarbeurs, pasar malem en jaarmarkten (Soerabaia: Hahn, 1928), I-4; A. E. Simon Thomas, Een en ander over de plaats der jaarmarkten in de Indische maatchappij: Prae-advies uitgebracht op de jaarvergadering der Vereeniging tot bevordering van het jaarmarktwezen in Nederlandsch-Indië, gehouden te Soerabaja op I3 October 1929 (Weltevreden: Emmink, 1929), I-I7. 
32. Programma van den Pasar Gambir (Batavia: Pasar Gambir Comité, 1922-1933). For instance, see "Pasar Gambir 1925," Pandji Poestaka, August 25, 1925; "Pasar Gambir 1936," Pandji Poestaka, August 28, 1936.

33. "De Luna Park Czar van het Oosten," D’Oriënt, September 24, 1938; Pewarta Deli, May 21, 1929, IPO, no. 22 (1929).

34. Programma van den Pasar Gambir (1923-1933).

35. Van der Meer, "Performing Colonial Modernity," 503-38.

36. Simon Thomas, Een en ander over de plaats der jaarmarkten, 7-8.

37. Indisch Verslag I93I, 221-22.

38. Programma van den Pasar Gambir (1923-1933); Jaarverslag Nederlandsch-Indische jaarbeurs (1929-1933).

39. Indisch Verslag (1931-1937).

40. "Inlandsche kunstnijverheid," D’Oriënt, August 30, 1924; "De Indische kunstnijverheid op den Pasar Gambir," D’Oriënt, September 5, I925.

41. Programma van den Pasar Gambir (1923-1933).

42. M. A. J. Kelling, "De eerste hygiëne-tentoonstelling in Nederlandsch-Indië," D'Oriënt, vol. 6, no. 26 (1927).

43. Kelling, "De eerste hygiëne-tentoonstelling," 63.

44. Kelling, "De eerste hygiëne-tentoonstelling," 63.

45. "Pemboekaan Pasar Gambir," Pandji Poestaka, September I, I93I and September 8, 1931; Programma van den Pasar Gambir (1923-1933).

46. Simon Thomas, De importeur, 9.

47. Dijkerman, "Het jaarmarktwezen in Nederlandsch-Indië," I27-32.

48. Simon Thomas, Een en ander over de plaats der jaarmarkten, 9-II.

"De jaarmarkt," De Indische Courant, October I2, 1927; "Hoe anderen den Pasar Gambir zien," NNI, September 7, 1929.

49. H. Cox, The Global Cigarette: Origins and Evolution of British American Tobacco, I880-I945 (New York: Oxford University Press, 2000), 279-83.

50. These percentages are rough indications based on Programma van den Pasar Gambir (1925-1927).

51. Programma van den Pasar Gambir (1923-1933).

52. Simon Thomas, Een en ander over de plaats der jaarmarkten, 17.

53. "Pasar Gambir," Pandji Poestaka, August 30, 1929.

54. "Eerste Ned: Indische reclame tentoonstelling," D’Oriënt, September 5, 1925.

55. Dutton, "Advertising, Modernity, and Consumer Culture," 2I-42; Liechty, Suitably Modern, 6-7.

56. Simon Thomas, Een en ander over de plaats der jaarmarkten, 7-II.

57. The currency in the Netherlands Indies was known as the Netherlands Indies Guilder (fl.). Programma van den Pasar Gambir (1925).

58. J. E. Jasper, Verslag van de eerste Semarangsche jaarmarkt-tentoonstelling, Igo8 (Batavia: Landsdrukkerij, I9II).

59. “Sambil laloe," Hindia Baroe, May 25, 1925; “Wit Java," Hindia Baroe, June 15, 1925. 
60. "Pasar Gambir," Pandji Poestaka, August 30, 1929.

61. "Pasar Gambir 1930," Pandji Poestaka, September 5, 1930; "Berdjalan-djalan kekota bamboe: Pasar Gambir," Pandji Poestaka, July 30, 1937.

62. Lukito, Exhibiting Modernity, 17-68.

63. "Electrische Lichtreclame," D’Oriënt, September 4, 1926.

64. F. van der Kooi to A. A. Cense, in Collection A. A. Cense, D OR. 545-305, UBL; "Pasar Gambir," Pandji Poestaka, 29 July 1932.

65. See graphs in Van der Meer, "Performing Colonial Modernity," 524-25.

66. At provincial fairs, the proportion of indigenous visitors was even larger than in the major cities. For instance, of the 134,993 visitors to Pekalongan's 1924 pasar malam, only 2 percent was European and 8 percent Foreign Oriental, while 90 percent was indigenous. J. E. Jasper, De organisatie van een jaarmarkt-tentoonstelling: De ze te Pekalongan (Tegal: De Boer, 1924).

67. "Pasar Gambir ke-I2," Pandji Poestaka, September 6, 1932.

68. "Pasar Gambir te Batavia," Algemeen Handelsblad, September 17, 1935.

69. Pandji Poestaka, September I, 1933.

70. See graph in Van der Meer, "Performing Colonial Modernity," 524-25.

71. "Rempah-Ratus: Pasar Gambir," Pandji Poestaka, July 30, 1937.

72. Schulte Northolt and Hoogevorst, "Urban Middle Classes in Colonial Java," 442-74; Schulte Nordholt, "Modernity and Cultural Citizenship in the Netherlands Indies," 435-57.

73. Dutton, "Advertising, Modernity, and Consumer Culture in Colonial Vietnam," 2I-42; Liechty, Suitably Modern, 6-7.

74. Bahagia, April 3, 1930, IPO, no. Is (1930).

75. Dijkerman, "Het jaarmarktwezen in Nederlandsch-Indië," I27.

76. Hardjo Soë, "Omong kosong: pemandangan tentang Pasar Gambir," Pandji Poestaka 16, no. 70/72 (1938).

77. Hardjo Soë, “Omong kosong: Pasar Gambir," Pandji Poestaka I3, no. 70 (1935).

78. Hardjo Soë, “Omong kosong: Pasar Gambir di Betawi," Pandji Poestaka I4, no. 7I (1936).

79. Taylor, "Costume and Gender," 85-116; Taylor, "Identity, Nation and Islam," IOI-I2O.

8०. Hardjo Soë, "Omong kosong: Pasar Gambir."

81. Persatoean Indonesia, June I, 1929, IPO, no. 23 (1929); “Tentoonstelling kolonial di Paris," Persatoean Indonesia 4, no. 5, October 7, 1931.

82. "Pertjoendjoekkan bangsa manoesia," Bintang Timoer, June 29, 1929; Darmo Kondo, May 17-18, 1929, IPO, no. 21 (1929).

83. "Het jaarmarktwezen," Timboel, August I5, 1928.

84. For a similar critique "Javaansche cultuurbeweging: Een passer derma," Djawa, no. 4 (1925).

85. Bendee, September I9 and 26, 1928, IPO, no. 40 (1928); Djanget, October I, 1928, IPO, no. 4I (1928); Sedijo Tomo, July 27, 1929, IPO, no. 3I (1929). 
86. What makes Pandji Poestaka such an interesting source is its continuous publication over a long period of time (1922-1945), which offers scholars the opportunity to trace and compare reporting over time.

87. Hardjo Soë, "Omong kosong: Pasar Gambir di Betawi."

88. Hardjo Soë, “Omong kosong: Pasar Gambir.” Hardjo Soë, “Omong kosong: pemandangan Pasar Gambir," Pandji Poestaka I5, no. 75 (1937).

89. "Pasar Gambir," Pandji Poestaka, August 28, 1924.

90. Sedijo Tomo, September 10, 1928, IPO, no. 8 (1928); Fadjar Asia, September 15, 1928, IPO, no. 8 (1928); Kristen Djawi, no. 26, IPO, no. 44 (1929).

91. "Pasar-pasar Malem bikin mlarat pada ra'jat," De Samenwerking, September 7 , 1929; De Samenwerking, March I5, 1930.

92. "Pasar-pasar Malem bikin mlarat pada ra'jat I," De Samenwerking, October 26, 1929.

93. "Pasar-pasar Malem bikin mlarat pada ra' jat I."

94. "Pasar-pasar Malem bikin mlarat pada ra'jat II," Samenwerking, November 2, 1929; "Soerat Terboeka: Passar Malem dan Pendjoedian," Samenwerking, September I3, 1930; "Doenia handel dan pasar Malam," Samenwerking, November 29, 1930.

95. Sinar Hindia, November 30, 1918, IPO, no. 48 (1918); Neratja, December 13, 1920, IPO, no. 5I (1920).

96. Taylor, "Costume and Gender," 85-116; Taylor, "Identity, Nation and Islam," IOI-I2O.

97. Oetoesan Hindia, January 13, 1921, IPO, no. 3 (1921); Kaoem Moeda, February 6, 1922, IPO, no. 7 (1922).

98. Vreede-de Stuers, The Indonesian Woman, 91.

99. Taylor, "Identity, Nation and Islam," IоI-I20.

Ioo. Kaoem Moeda, April 7, 1924, IPO, no. 16 (1924).

ıог. "Berdjalan-djalan ke Pasar Gambir," Pandji Poestaka, September 4, 1924.

102. Pantjadjania, May 21, 1926, IPO, no. 24 (1926).

I03. Hardjo Soë, "Omong kosong: pemandangan Pasar Gambir."

I04. Djawa Tengah, January 5, 1920, IPO, no. 6 (1920).

I05. Boedi Oetomo, January 19, I921, IPO, no. 4 (1921); Persamaan, August 20, 1924, IPO, no. 36 (1924).

I06. Hardjo Soë, "Omong kosong: pemandangan dalam Pasar Gambir," Pandji Poestaka 13, no. 72 (1935).

107. Darmo Kondo, January 28, 1925, IPO, no. 6 (1925).

108. "Sambil laloe," Hindia Baroe, May 25, 1925.

ı09. "Ketel nasional," Bintang Timoer, April 8-13, 1931; "Batik kita dan lurik kita," Aksi, June 25, 1931.

IIo. The original proposal for organization of a pasar malam derma came from Gondokoesoemo, appointed treasurer of the organizing committee. The periodical of the Indonesian Study Club, Soeloeh Ra' jat Indonesia (Torch of the Indonesian People), published a special issue to reflect on the first fair. "Nomor Pasar-Malem 3I Mei-9 Juni," Soeloeh Ra'jat Indonesia 4 (1930). 
III. "Nomor Pasar-Malem 31 Mei-9 Juni," I-2.

II2. Vreede-de Stuers, The Indonesian Woman, 6I-74.

I13. "Nomor Pasar-Malem 31 Mei-9 Juni," front page and page 4.

I 4. Cohen, Inventing the Performing Arts.

II5. Nomor Pasar-Malem 3i Mei-9 Juni," 7.

II6. Elson, The Idea of Indonesia, 39-72; Nomor Pasar-Malem 31 Mei-9 Juni," 3.

"Teekende feiten," Bataviaasch Nieuwsblad, June 5, 1931.

I17. "Pasar Malem derma nasional," Swara Oemoem, May 23 and 26, 1931; "Pasar Malem derma nasional ka 2," Swara Oemoem, May 27, 28, and 30, I93I and June I, I93I. I18. The financial results can be found in "Nomor Pasar-Malem 31 Mei-9 Juni," I2-I3. 119. Sedio Tomo, June 19 and 20, 1930, IPO, no. 26 (1930); Bintang Timoer, June 12, 1930, IPO, no. 25 (1930).

I20. The objective was to organize the Pasar Malam Nasional annually, but both for economic reasons (the crisis years) and political reasons (discord with the nationalist movement) it only opened it gates five times: in 1930-1933 and in 1937.

I2I. Compare Joshi, Fractured Modernity, I-22.

I22. Steijlen en Willems, Met ons alles goed, i24.

Epilogue. Pawnshops as Stages of the Colonial Performance of Power

I. De Zweep, January is, 1922.

2. Staatsblad, no. 393 (1906).

3. "Keloeh kesah," Doenia Bergerak, June 20, 1914, 9-10; "B. B. contra pandhuis," Doenia Bergerak, November 7, 1914, 8-9.

4. Oetoesan Hindia, March 26, 1919.

5. Oetoesan Hindia, April 3, 1919.

6. G. A. J. Hazeu to R. A. Kern, September 21, 1922, in Collection Kern, H 797, no. 291, UBL.

7. R. A. Kern to D. Fock, January 23, 1922 and March 16, 1922, in Collection Kern, H 797, no. 291, UBL; Akira Nagazumi, "The Pawnshop Strikes of 1922 and the Indonesian Political Parties," Archipel 8 (1974): 187-206; Een en ander naar aanleiding van de staking bij den Pandhuisdienst (Yogyakarta: H. Bruning, 1922).

8. NNI, March I8, 1920.

9. NNI, February 4, 1920. Het Indische Leven, August 7, 1920 and April 24, 1926.

Iо. “Djanganlah sampai loepa daratan!," Pandji Poestaka, January 31, I940.

II. John Pemberton, On the Subject of “Java," I-27. 